\title{
VICTORY IN HADES: THE FORGOTTEN WARS OF THE OMAN 1957-1959 and 1970-1976
}

\section{PART 2: THE DHOFAR CAMPAIGN $1970-1976$}

\author{
S. Monick*
}

\section{Section A}

\section{Similarities and contrasts}

During the years 1970-1976 Oman was once again a theatre of operations in which the Sultan's forces, supported by pro-Western powers, succeeded in defeating the insurgent forces seeking to destroy the established power structure of Oman. In many respects, the political configuration of this second war bore many close resemblances to the first ${ }^{1}$. One had, as in the first campaign of 1957-1959, the active military participation of Britain; in terms of both leadership and the active involvement of British units (including the Special Air Service Regiment SAS - who, as in the first Omani campaign, were to play a major role in the war). One also has the same motivation underlying British participation; viz. the determination to retain Oman's crucial strategic position (centring upon the Musandam Peninsula, and its control of the Straits of Hormuz). Moreover, as in the first Campaign, one observes the active participation of neighbouring states of the Middle East in support of the Sultan; in the war of 1957-1959 these states comprised the Trucial Oman States, to which Britain was closely related via long standing treaty obligations, and whose active military support was manifested in the presence of the Trucial Oman Scouts (TOS). In the latter Campaign of $1970-1976$, the support emanated from Jordan and Iran.

However, within this broad context of parallel political configuration, multiple differences between the two campaigns become apparent. If one disregards the obvious difference of geographical emphasis (i.e. the first war of 1957-1959 centred upon the Jebel Akhdar in the north of Oman, whereas the second focused upon the province of Dhofar in the far south west), a number of important contrasts emerge in a comparison between the two campaigns. First, the underlying pressures impelling the insurgent forces were of a different nature. In the first war, the paramount factor underlying the insurrection was traditional tribal seperatism (admittedly with the active support of Saudi Arabia and Egypt), compounded by the deep rooted friction between religious authority (vested in the Imam) and secular power (embodied in the Sul$\tan )$.

However, in the latter conflict, the paramount influence in the insurgency was Communist subversion (manifested in the insurgent movement designated the Popular Front for the Liberation of Oman, or PFLO); functioning as an extension of the power of a neighbouring Marxist state (The People's Democratic Republic of Yemen PDRY). Thus, covert Communist expansionism was a real and potent factor in this latter conflict. The evolution of historical processes is an important consideration within this context. In 1957-1959 the practice of insurgency had developed only to a limited extent. The outstanding illustration of the success attendant upon insurgency modelled upon Maoist principles was the Vietminh offensive in French Indo-China $(1946-1954)^{2}$. The Communist insurgency in Malaya (1948-1960) was visibly waning, its defeat inevitable. Similarly with the Hukbalahap ('Huk') insurgent offensive in the Philippines. However, the 1960's witnessed the emergence of insurgency as a developed and highly successful instrument in the destruction of established powers. The success of insurgency as a political weapon in the ensuing decade was, of course, signalled by the success of the Cypriot insurgent movement (EOKA) in expelling the British from Cyprus in 1958-1959. It had triumphed in expelling the French from Algeria and the British from Aden in 1962 and 1967 respectively (although, in both instances, due to political 
capitulation rather than military defeat). In South Vietnam, Angola, Mozambique and Rhodesia it was developing impetus. Thus, the insurgent forces in the Dhofar war gained an enormous momentum from the global precedents of the preceding decade.

Moreover, the role of Britain, in relation to Oman, was of a very different complexion in 1970-1976 to what it had been in 1957-1959. In this second Omani war Britain had relinquished all power in the Middle East. Its surrender to Marxist insurgent forces in Aden in 1967, and consequent evacuation from South Arabia in the same year, had finally signalled Britain's total abdication of power in the Arabian Peninsula; a decision confirmed by its departure from Bahrain in 1971, thus completing her total withdrawal from east of Suez. This abdication of power was further manifested in the cessation of Britain's treaty obligations with the Trucial Oman States, and the replacement of this political entity with the United Arab Emirates (formed in 1971). Hence, in this second campaign Great Britain was an intruder, so to speak, in the affairs of the Persian Gulf to an extent not apparent in the war of 1957-1959, when her intervention could be justified in terms of her military and political presence in neighbouring South Arabia (i.e. in terms of her interest in maintaining stability within a region in which she had a powerful vested interest). A further most important dissimilarity between the two campaigns was that a different Sultan (Qaboos), possessing quite different attitudes from his predecessor, was in power.

The above contrasts abviously relate to the political configuration of the second Omani war. However, the military aspect of the war also presents very real contrasts. It can with justice be asserted that the scale of operations in the Dhofar campaign was far more extensive than in the Campaign of 1957-1959. In the first war the key to the defeat of the insurgents resided entirely in the capture of the rebel redoubt of the Jebel Akhdar (the 'Green Mountain'). In the Dhofar campaign, however, the issue centred upon the creation of 'cordon sanitaires' across the face of the province (the principal examples of which were the Hornbeam and Damavand Lines), within which the insurgent forces could be pressured and isolated, combined with sweeping vertical envelopment manoeuvres. In short, whereas the war of 1957-1959 was tactical in conception and execution, the key to success in that of 1970-1976 was conceived and executed primarily in strategic terms. Moreover, the military technology characterizing the two campaigns was of a different order. Especially noteworthy within this context was the enhanced role of helicopters and the sophistication of anti-aircraft weaponry (in the form of SAM-7 missiles).

A further contrast within the military context was that, unlike the war of 1957-1959, civil development of the theatre of operations complemented the purely military reaction to the insurgency. With regard to this factor, the role of the SAS crystallizes the profound contrasts concealed within ostensible similarities of military approach. Whereas the SAS performed a crucial role in the decisive action which resolved the first conflict (i.e. the storming of the summit of the Jebel Akhdar), in the crucial engagements of 1975 the SAS played no major role. The purely military climax of their involvement in this second Omani war was the siege of Mirbat in 1972, which will be discussed below. Throughout the second Campaign the Regiment's participation was of a far more subtle and unorthodox nature than the conventional military role - that of specialized mountain assault troops - which characterized their intervention in the war of 1957-1959.

It should be borne in mind that military and political processes are rarely mutually exclusive; they constantly interact and reinforce one another. Thus, within the political context Britain's capitulation to the insurgent forces in South Arabia (the overtly Marxist National Liberation Front - NFL and the Front for the Liberation of Occupied South Yemen, or FLOSY; the former of whom captured control of the country) was a necessary prelude to the projection of the power of the NFL in their newly captured state into neighbouring Oman (via Dhofar) in the form of both active support for insurgent forces within Dhofar and, as the war moved west towards PDRY, direct military intervention by South Yemen. In other words, it was the British evacuation of South Arabia which facilitated the NFL's 'export of revolution' into Oman. Similarly, the active policy of civil development, the direct consequence of Sultan Qaboos's far more liberal attitudes, manifested itself in the close interrelationship between military response and civil re-construction programmes.

\section{Approach and organization}

The approach and organization of this paper merits some comment, as it does not follow an orthodox pattern. In other words, the most ob- 
vious approach - which would be to discuss the Dhofar campaign in chronological sequence - is not pursued. Rather, the salient thematic features of the Campaign - centring upon the role of the SAS in their training and leadership of irregular forces and their formulation of a 'hearts and minds' campaign - are discussed prior to analysis of the actual operations of 1975 which proved, unexpectedly, to be the year of decision. These features pre-date and parallel the Campaign history proper (e.g. the attack on Mirbat in 1972, the firqat operation of January 1975). Hence, it would appear that the ordering of material in this paper is somewhat haphazard, often being out of sequence. Such an approach, however, has been moulded by the essential objective underlying all three parts of this history of the wars in the Oman. This objective transcends the recounting of a narrative history and is, rather, centred upon the intention to extract certain features which are of universal and generalized significance for counter-insurgency (COIN) operations (including those waged in Southern Africa). Thus, the role of the SAS in this second Campaign in Oman is so closely interrelated with the entire issue of 'hearts and minds' - so conducive to extensive debate in any discussion of COIN operations - that this theme transcends the actual chronological study of the war of 1970-1976.

\section{The Geographical context}

The province of Dhofar is approximately the size of Wales. Its two major geographical features are the inland coastal plain (the Salalah plain) and its mountainous range (the Jebel Massif). The jebel is situated inland from the Salalah plain parallel with the coast and extending for some 150 miles down to the border with PDRY. The jebel varies widely. At its highest point its height does not exceed a modest $3000 \mathrm{ft}$, but it rises steeply from the plain to a plateau comparatively narrow in the east and west, but some nine miles in width in the centre. The fertility of the plateau appears incongruous within the context of South Arabia (as does that of the Jebel Akhdar), and is due to the rains caused by the south west monsoon (the 'khareef'), which blankets the plateau with cloud and mist between June and September. Grass is luxuriant in the region, and great rolling downs stretch as far as the watershed to the north. This watershed (the 'gatn') consists of uninteresting flat land of small rocks and bushes on the edge of the khareef mist and thus still deriving some moisture from it. Being so flat it facilitates easy movement from one end of the jebel to another. In 1970 one could locate barely identifiable airstrips; some from past SAF operations, and other utilized by civilian oil exploration teams. A prominent feature of the jebel are the wadis, which run down to the plain like great gashes, and extend for hundreds of yards across. They begin in the north as mere indentations but quickly fall away into steep re-entrants and glens filled with thick bush. As they run further southwards they become progressively deeper and wider until, at the entrance to the plain, they might be several hundreds of yards across, with great precipitous flanks rising sharply to the plateau. The wadi bottoms have formed natural routes for centuries. Generally speaking they lend themselves to north-south movement, but the east-west wadis offer easy routes up to the plateau, across it, and down to the next major wadi. The most important feature of the wadis is, of course, that they contain the water upon which all life depends; in the form of clear sweet pools set under rocks in shady glades, or in natural waterholes often developed into tanks with cement and stones by the jebelis or, in certain places in flowing streams. As one moves towards the border with PDRY the plateau entirely disappears and the jebel becomes a series of escarpments covered with grass and camel bush, running down to the sea. There is less vegetation in the wadis, which becomes more sheer and stark, with huge precipices. Beyond the 'gatn' lies the 'negd', a dry, pastureless, featureless moonscape of shingle and small rocks, split by boulder-strewn and sand-filled wadis. They become shallower, with wide flat bottoms, as they run north until they finally disappear into a great gravel plain, and eventually merge into the sand sea of the Empty Quarter.

This geographical configuration was to structure the nature of the war in Dhofar. The mountain fastnesses were to provide an ideal sanctuary for insurgent forces. Blanketed with vegetation, they are virtually impenetrable to vehicles. This is excellent bandit territory, honeycombed with small caves which provided excellent refuge for small guerrilla bands, whose tactics were those of ambush, intimidation and raids upon the villages of the plains under cover of darkness, when mines could be laid along the tracks used by security forces. Accordingly, the success of the COIN response could only be effectively measured in terms of the extent to which the Sultan's forces re-established their authority on the jebel. Moreover, a great deal of military activity was directed towards the wadis, which constituted the insur- 
gents' major source of water supply. The thick bush which characterized the wadis determined the tactics of ambush and evasion, in contrast to the open warfare of the plain.

\section{The ethnic context}

It should be borne in mind that the rebels of the jebel possessed close ethnic sympathies with their neighbours of South Yemen. To the Dhofaris of the Jebel Massif there was a common bond with the hill peoples of the newly established Marxist state on their borders, in contrast with their attitude towards the Sultan, who was viewed as ' 'puppet' of the British, a plainsman entrenched behind his palace walls at Salalah, with an escape route to the sea guarded by foreign mercenaries. As is characteristic of many tribal geographical configurations within Africa, in which artificially imposed colonial boundaries disregarded ethnic concentrations, several of the tribes of Dhofar were distributed over national boundaries. An example were the Mahra, who represented a nation rather than a tribe. They controlled much of the interior of South Yemen in addition to large tracts of Western Dhofar. Mahra was virtually unadministered during British rule, its Sultan living hundreds of miles away on the island of Socotra, but the Hadhrami Bedouin Legion had manned a fort at Habarut on the Dhofar border. Habarut was linked with Hauf on the coast by a crude truck; and Hauf was where weapons and mines were landed by dhows from Aden. In short, the entire area provided an excellent base for insurgent incursions into neighbouring Dhofar, and the prominent tribe of the region could rely upon many sympathisers among their kinsmen over the border. This ethnic affiliation with PDRY was accentuated by the Dhofaris' alienation from the other inhabitants of Oman. Being seperated from Northern Oman by a desert approximately 400 miles in extent, there are inevitably major differences in culture and social background between the two. Indeed, the Dhofaris are not true Arabs at all. They are believed by some to have originated in Ethiopia, and their facial features certainly resemble Ethiopians or Somalis more than the true Arabs of the north. As is the case with Somalis also, Dhofaris exhibit a fierce pride in their herds of cattle; they build round houses of stone and straw which strongly resemble Somali manyattas and one frequently encounters old men leaning on a staff and resting on one leg with the sole of the other foot placed against the inside of the knee, reminiscent of the typical
Somali stance. The language of Dhofar is termed Jebeli, an unwritten language totally different from Arabic and thought to have originated in Aramaic.

\section{The contagion of Aden}

Sultan Said ibn Taimur's centre of power resided in Dhofar. He managed the province as though it were his own private estate, and took as his wife a Dhofari woman who was the mother of his heir, Qaboos (cf. below). His Headquarters was his palace at Salalah, whence he had moved in 1958. The Sultan's writ was inforced within a limited distance from Salalah by the 'Dhofar Force', commanded by Maj St John Armitage and consisting of approximately 200 Baluchi soldiers. As intimated in Part 1, this Dhofar force was entirely independent of the Sultan's Armed Forces (SAF); comprising the Sultan's personal bodyguard, so to speak. This force was badly equipped and underpaid (a state of affairs symptomatic of the Sultan's obsessive fear of bankruptcy) and did not enlist Dhofaris. (This was in accordance with the Sultan's antagonism to any concept of 'Arabization' in his armed forces at all levels' a feature which has been discussed in Part 1). After 1961 the Dhofar force was trained and led by seconded officers and NCO's from Pakistan. Dhofar was no exception to the appalling dearth of civil development that charctarized all Oman and which was a testimony to the Sultan's reactionary attitudes. An organization calling itself the 'Dhofar Liberation Front' (DLF), led by Masallim bin Nuffl initiated a limited insurgency programme, exploiting the inhabitants' (admittedly very real) grievances. Between 1962 and 1965 the Sultan endeavoured to combat this with the Dhofar force, but met with little success. The SAF were consequently drawn into the conflict.

Until 1967, across the border in South Yemen, left wing Arab nationalists had been engaged in a campaign against the British controlled South Arabian Federation (comprising the port of Aden and the Western and Eastern Protectorates). It was inevitable that the contagious example of the insurrection within the South Arabian Federation would lend considerable impetus to the Dhofar insurgency. Dhofari tribesmen, trained in Iraq, intensified their campaign of armed ambush, mine-laying and assassination. The insurgency assumed several new complexions after the evacuation by the British from South Arabia in November 1967, and the consequent emer- 
gence of the newly independent state of South Yemen (formally designated the People's Democratic Republic of Yemen - PDRY), controlled by the Marxist National Liberation Front (NFL). The first major change of aspect was that of degree. The insurgency within Dhofar gained tremendous impetus. It was apparent that the Sultan's opponents in the mountains now had far greater room for manoeuvre. It is, of course, axiomatic to guerrilla warfare that sanctuary for insurgents and a secure base for war materials - preferably contiguous to the war zone - must be established if success was to be guaranteed. After the success of the NFL in South Arabia in 1967 the Dhofari insurgents possessed precisely this advantage.

The second major change of aspect induced by the Marxist seizure of power in Aden and South Arabia was that the leadership of the insurgency in Dhofar underwent a transfer of power; from the factious tribal leaders to deeply indoctrinated Marxist political movements, sponsored by and based in the South Yemen; namely, the Popular Front for the Liberation of the Occupied Arabian Gulf (PFLOAG). After the British had completely withdrawn from the Persian Gulf the movement changed its name to the People's Front for the Liberation of Oman (PFLO). PFLOAG - as it then was - made overtures to the DLF and suggested that the two should join forces in the face of the common enemy. The DLF were, initially, most reluctant to be allied with the atheistic Marxist forces of the PFLOAG. However, finally seduced by the money and superior weapons that the PFLOAG could provide, they agreed. Inevitably, as is characteristic of all movements infiltrated by Communist political groups (cf. Section B, which follows this paper), the traditional leadership of the DLF was completely supplanted by their new Marxist allies; the former could not possibly counter the well organized, energetic and highly motivated Communists. Within a short time cells were established throughout the jebel, whilst discussion groups and propaganda eroded the traditional tribal loyalties of the jebelis. The succeeding phase was the destruction of the traditional tribal structure by means of persuasion, fear and corrosion. Tribal elders and Sheikhs were killed, often with extreme cruelty. For example, in Western Dhofar five elderly Sheikhs were pushed over a cliff $450 \mathrm{ft}$ in height; whilst at Dalqut the Sheikh and his sons were stood against the walls of their house and machine-gunned. Children were forcibly removed from their parents to be sent to school in PDRY (especially to the Lenin School of Hauf), whilst young men were sent to China and Russia for training in guerrilla warfare. The Communist atrocities escalated as their control intensified; fathers were forced to offer their daughters to the young fighters as their duty to the PFLOAG, and old men had their noses cut off and were blinded with red hot knives for refusing to deny Islam. (However, these actions ultimately reacted favourably upon the Sultan's forces, in so far as it provoked a counter-revolution by Islamic traditionalists within the DLF. Although this counterrevolution was suppressed, it did result in an influx of defectors to the Government forces, as will be discussed below).

By 1970 the unsurgents - now firmly under the control and leadership of the PFLOAG - controlled the entire jebel, the Sultan's forces holding authority only in Salalah and, to a lesser degree, in the coastal towns of Taqa and Mirbat, which the adoo (insurgents) tolerated as sources of re-supply of food and ammunition and even as rest centres for their fighters.

\section{The decline and fall of Sultan Said ibn Taimur}

Inevitably, as the rebellion against Sultan Said's rule gained momentum, internal opposition to his regime (not necessarily dependent or interconnected with the external forces of subversion but nevertheless emboldened by them) gained audacity. There was a dramatic illustration of this in 1966, when there was an assassination attempt on Sultan Said's life. Whilst the Sultan was inspecting his own bodyguard they fired at him from the range of a few foot; they missed. It is characteristic of Sultan Said's heroic fatalism in the face of such traumatic events (earlier revealed by his attitude towards the annihilation of his forces in $1957^{3}$ ) that, immediately following this attempt upon his life, he then drove down to the principal Army garrison (leaving behind a wounded Pakistani palace guard commander) to inform its British commander, "We seem to be having trouble down at the palace. I wonder if you would be so good as to come down?'

Underlying the intensifying opposition to the Sultan's rule was the knowledge that a trained and able successor was ready to assume control. Qaboos was the son of Sultan ibn Taimur by Mizoon, the daughter of Sheikh Ahmed Ali of the powerful Bait Ma'asheni tribe of Eastern Dhofar. Qaboos's principal crime in his father's eyes was that, after receiving a traditional Islamic educa- 
tion, he had been extensively educated in the West; having attended the Royal Military Academy, Sandhurst, and been commissioned in the Cameronians. He had, moreover, undertaken a detailed study of British institutions with regard to industry, local government, etc. In view of his father's xenophobic attitude towards western ideas (and, no doubt, remembering that he had himself deposed his own father), it is hardly surprising that Sultan Said placed his own son under virtual house arrest in Salalah upon the latter's return in 1963.

The end for Sultan Said came in 1970. On the afternoon of 23 July 1970 , less than a month after the election of Edward Heath's Conservative Government in Britain, Sheikh Braik bin Hamud bin Hamid al-Ghafari, an Omani aristocrat and the Wali (Governor) of Dhofar, entered the Salalah palace with a group of armed supporters to demand the abdication of Sultan Said. It was an undeniable act of courage, buttressed by the Sheikh Braik's knowledge that Qaboos - his close friend - as well as key British officers were part of the plot. The Sultan responded to this unprecedented demand by seizing a pistol from his desk and opening fire. One round wounded the Sheikh, another killed a palace servant, and several more wounded the Sultan in the foot and stomach. That night Sultan Said agreed to surrender himself to a British colonel seconded to his armed forces, and to abdicate. Both Sheikh Braik and the Sultan were then flown to a Gulf hospital aboard the same aircraft, seperated only by a curtain; the RAF subsequently spiriting Sultan Said away to London, where he spent the final two years of his life in seclusion. Sultan Qaboos ascended the throne on the day that Sultan Said's abdication was demanded and obtained (23 July 1970).

\section{New directions}

In this study 1970 is regarded as the year in which the second major conflict in the Oman began. It may be argued that the impetus to this second insurrection had been developing in the preceding decade within Dhofar (and especially in the Jebel Massif), particularly after the British evacuation from South Arabia in 1967. Such an argument is completely valid. However, in 1970 the response of the established Government in Oman adopted a form not apparent in the preceding decade. Thus, whilst the insurgency was assuming a very different complexion form that which had characterized the rebellion of
1957-1959, the response of the beleagured Government forces was simply an extension of the COIN operations of 15 years earlier. To reiterate, this new response manifested itself in multiple facets; the two most significant being the far more extensive scope of manoeuvre and the very different approach of Sultan Qaboos towards the question of civil development which, as intimated above, became an integral aspect of the military counter-offensive. Integral to this new approach was the extremely active role assumed by 22 Special Air Service Regiment from 1970 onwards. Although this facet of the second COIN assault of 1970-1976 may ostensibly appear to be but the continuation of the British response of 1958-1959, in actual fact it lent a markedly different aspect to the Campaign of 1970-1976. The role of the SAS, therefore, merits detailed attention.

\section{‘Operation storm': The SAS intervenes once again}

The new emphasis on 'hearts and minds': Three senior officers of the SAS had spent the Easter of 1970 examining the Dhofar problem and seeking to devise a winning strategy. Such a strategy had been moulded by observation of the military developments of the 1960's. To reiterate, this decade had been especially characterized by the increasing momentum of the concept of guerrilla war and 'low intensity operations'. The continuing conflict in Vietnam at that point in time, as well as confrontation with Indonesian forces in Borneo during the years 1962-1966, had led the senior SAS officers to believe that a winning strategy, in an age of revolutionary fish swimming in a proletarian sea, was a matter of shaping the perceptions and loyalty of the population at large. By Easter Monday one of these three officers ( Lt Col John Watts, Commanding the SAS Regiment), had produced a plan of operations for what was to become 'Operation Storm' in Dhofar. The plan demanded a vigorous but intelligent and coherent military campaign conducted by soldiers in which indiscriminate reprisals against the civilian population (which had tended to be a consistent theme in Sultan Said's response) was to be avoided. The other basic elements in the strategy were:

(i) A veterinary campaign to improve farm stock, including the provision of that most scarce commodity, fresh water, as well as skilled advice regarding husbandry.

(ii) A medical campaign to provide aid for the 
50000 or so inhabitants of the Dhofar mountains, who were indiscriminately blanketed with the designation of 'enemy' by the administration at Salalah.

(iii) A coherent and co-ordinated intelligence gathering operation that would encompass every detail concerning the rebels; with the object of isolating the insurgents and breaking their morale, as well as underpinning military operations.

(iv) A psychological operation intended to persuade the rebels to change sides; the fundamental components of which were communication by air-dropped leaflets, offer of amnesty to tribesmen wishing to surrender and a comprehensive information service.

Sultan Said's regime, by its very nature, could not be expected to be responsive to such a daring and imaginative application of the "hearts and minds' approach; predictably, it was regarded with great suspicion in 'informed circles'. Moreover, it required a far greater degree of coordination and discipline that was at that point in time manifested by the military leadership in Salalah. To take a major example, the existing use of air power - then consisting of six Strikemasters - was, in the view of one SAS officer, remarkably informal. 'At that time', he commented, 'the Sultan's Air Force operated in an ad hoc way. The pilots seemed to sit around the mess in Salalah, then someone would suggest, off the top of his head, 'Let's go and hit such-and-such a place." ${ }^{\prime 4}$. Systematic air support for infantry operations did not exist.

The advent of the new regime, however, granted the new approach a degree of political acceptance on the part of the Sultanate that it could never have realized under the old regime. The removal of Sultan Said, therefore, provided the SAS with its first opportunity. Within hours of the palace coup a small SAS group (officially designated an 'information team') was journeying to Salalah, led by the principal architect of the new 'hearts and minds' win strategy.' They provided an instant bodyguard for the new Sultan about whom there is a story (possibly apocryphal) that it (i.e. the bodyguard) stood behind a two-way mirror whilst Qaboos received petitions; instinctively moving towards its weapons in response to every (characteristically Arab) florid gesture on the part of the petitioners.

\section{The amnesty campaign: a double-edged weapon:}

One of the first SAS operations, in accordance with the new strategy, was a leaflet drop over rebel territory. Despite the very real objection that only a small minority of the tribesmen were literate, the exercise produced a dramatic and unexpected prize, in the form of the defection of a leading insurgent. This was Mohammed Suhail, a former soldier in the Trucial Oman Scouts. Suhail had attended the Mons Officer Training Scool at Aldershot, sponsored by the Foreign and Commonwealth Office. He was a good soldier (being the best rifle and machine-gun shot on his course, and had been placed first on the FCO sponsorship list). Upon his return to Oman, however, he was disillusioned with Said's regime and joined the rebels in the mountains. The first leaflet, containing an offer of amnesty from the new Sultan, induced Suhail to defect form the insurgents and work with the SAS and the Sultan's Intelligence Staff, headed by an SAS officer. The amnesty campaign undoubtedly yielded fruitful results. As intimated above, reaction by the traditional members of the DLF to the Communist seizure of control considerably accelerated the rate of defections from the PFLOAG camp. The counter-revolution occured on 12 September 1970. The PFLOAG ordered the disarming of the DLF but, although surrounded, the hard core members of the latter in the Eastern area of Dhofar refused to comply and chose, instead, to defect to the Government forces. Between September 1970 and March 1971 , encouraged by promises of money as well as amnesty, a total of 201 rebels surrendered. Some surrendered their Kalashnikov AK-47's and were paid an additional bounty of $£ 50$. However, the serious dangers attached to such a programme should not be overlooked. The scheme was seriously criticized by some British soldiers on the completely valid ground that it supplied much war material to the rebels; in so far as the price paid by the security forces was that rebel camel trains conveying arms and ammunition and other supplies had unrestricted access to, and egress from, the mountains, during the period in which free movement of men and animals was permitted so that the insurgents could take full advantage of the amnesty offer.

\section{The Firqats: Strengths and Weaknesses of Irregular Counter-Guerrilla Units:}

The defection of former insurgents resulting form the amnesty campaign was an integral aspect of the SAS's role in the combat sphere of operations; viz. the training of irregular units of Dhofaris (firqats), many of whose leaders - as well as the rank and file - were former insurgents. The defectors - officially designated surrendered 
enemy personnel (SEP) were encouraged to join (and in some cases to lead) the firqats in order that their example would generate further defections from the enemy (the 'adoo'). Such a policy was shrewdly based on the extremely tight-knit tribal structure which characterized the social system of Dhofar. In those cases where firqat leaders were very closely related to their counterparts in the adoo, the former would exert considerable pressure upon the latter to defect to the Sultan's cause (as, in fact, commonly occured). The first of the firqats to be founded was designated Salahadin (after the renowned Saracen leader of the 12th Century who was so successful against the Crusaders) and its first leader was an adoo defector, Salim Murabak, who, whilst serving with the adoo, had been secondin-command of the entire Eastern Area of Dhofar. ( $\mathrm{He}$ died early in the Campaign, presumably of natural causes). Other firqats included the ' $A$ 'asifat', 'Al Nasr', 'Khalid Bin Waalid' and the 'Tariq Bin Zeed'. Few features of the second Omani Campaign were to generate such fierce controversy as the concept of the firqat.

The training, management and leadership of these firqats was one of the most important tasks undertaken by the SAS in its role as a British Army Training Team (BATT). BATT centres were established at Um al Gwarif (BATT Headquarters), Taqa and Mirbat. (The term 'Bat' was the almost universal term applied to SAS personnel. Indeed, members of this elite unit were very rarely referred to by their proper regimental designation. Even at the end of the war, when two Dhofaris dined in the SAS mess at their Headquarters in Hereford, they were amazed to discover that there was no 'Bat' regiment.) As the Campaign gathered momentum, SAS soldiers were sent for intensive 10 week courses in colloquial Arabic at the Royal Army Education Corps School of Language at Beaconsfield. By mid1974 there were approximately 16 firqats, consisting of some 1000 men. This figure had increased to 21 firqats (1600 men) in January 1975. When the war finally ended in 1976 the firqat numbers had increased to 2500 . One could identify three phases in the firqat's development; the first phase, one of recruitment and training; the second, main operational, phase, establishing the firqat in their tribal area (i.e. eliminating the insurgents from this area, with the assistance of a company or battalion of SAF and as many BATT personnel as possible); and, thirdly, orientating the firqat towards civil action projects (e.g. a well drilled, a clinic, school and shop built, etc.) At the completion of this third phase the BATT and SAF assistance withdrew, freeing them to assist other firqats in their early stages of development.

The firqat technique was very far from being an unqualified success. There were furious debates within the SAS concerning the resentment generated in the SAF as a result of paying some of the firqats better wages than the Sultan's regular soldiers, as well as supplying the firqats too generously with automatic rifles, ammunition and blankets. This school of thought (proponents of what might be termed the 'lean-and-mean' style of managment) would point to the fact that at Mirbat, during the first end-of-fast festival after Ramadan, the local firqat celebrated by firing 5000 rounds - almost the entire garrison stock of ammunition - and hundreds of FN rifles disappeared.

Moreover, there were chronic problems of command, which was critically dependent upon the SAS team leader and his tribal second-in-command. According to one British veteran, every firqat experienced a mutiny, of varying degrees of intensity, at some time and several units had to be disbanded. These problems were minimized when the SAS leader completely identified himself with his soldiers. Generally speaking, however, SAS teams served with the firqat but were not one of them. They lived and ate apart, preserving their identity even if the space between the two groups was only a matter of yards. -(This was, in fact, the only practicable course to adopt. Very few Westerners can identify with the mores and patterns of thought of Arab culture. Even Europeans who spoke the language fluently and served with Arab forces for many years could never secure the total loyalty of their soldiers. An outstanding example is the fate that befell Maj Pat Gray, commander of the Hadhrami Bedouin Legion which policed the Eastern Aden Protectorates of the former British ruled South Arabian Federation, who was assassinated by his own troops in $1966^{5}$. In his book, Imperial Sunset: Frontier Soldiering in the 20th Century ${ }^{6}$ Maj Gen Lunt makes the trenchant point that there could never be the same close identification of British officers with their Arab troops as existed in African regiments such as the King's African Rifles and the Royal West African Fronteir Force. Maj Gen Lunt quotes an incisive comment on this state of affairs from a letter written to him by Maj F.E. White ${ }^{7}$, who served with both the King's African Rifles and Aden Protectorate Levies, and compares the contrasting attitudes of the troops in both units: 
'My experience with Arab troops left me with the very firm impression that they largely managed thier own affairs and were dependent on British officers only in the spheres of training and administration. I frequently found that I was little more than an onlooker, hesitant to change things which might perhaps have benefited from change, ready to accept that standards were not necessarily better or worse, but in many respects very different to those to which one had grown accustomed elsewhere, and ruefully aware that there were spheres of life and influence in an Arab unit from which British officers were totally excluded ... Arabs, too, had through their devout faith the firmest possible belief in a devine guidance in all things, even to their destiny. This was far more influential than any advice or example from a British officer, or from any other mortal for that matter.'

It should be noted that Maj White is writing of a disciplined regular unit, with a long tradition of seconded service by British officers. In the light of his comments, the difficulties experienced with ill-disciplined tribesmen serving as irregulars, in whom was ingrained a hereditary tradition of tribal seperatism (and, moreover, in which many - including the leaders - had been newly weaned from the insurgent cause) can be analyzed in their correct perspective. In actual fact, the formal command relationship between the BATT leader and his firqat charges tacitly recognised this problem; in so far as the BATT commander was only an adviser. He could advise, but had no executive authority.)

The endemic problems of command ultimately derived from the social fabric of Dhofar, which centred upon an extremely democratic tribal structure. The essence of this structure is concisely described by Col Jeapes ${ }^{8}$ :

'The Dhofari tribal system, for all its faults, is possibly one of the finest examples of true democracy known to man... Tribal leaders are elected on merit because of their personal virtues. Heredity and class are meaningless; and even when elected the leader is by no means paramount; he must consult on almost everything he does and all major decisions are arrived at collectively after every man who wishes to do so has had his say ... It took the SAS some time to understand this and many SAS officers never understood it. A disciplined tribal unit is a contradiction in terms. Discipline, in the military sense that it is understood by a regular army, cannot possibly be achieved when everyone in the army thinks he has as much right to decide what is to be done as his leaders, and if he dislikes their decision feels free to take no part in the outcome.'

There were several notable instances of insubordination upon a scale that it would be difficult to credit in European armies. One outstanding example occurred in March 1971, during which the firqats, under the guidance of their BATT mentors, were seeking to establish a foothold on the jebel. One of the firqats had located an adoo piquet in the Wadi Arzat, in the eastern sector of the jebel, in the vicinity of the towns of Um al Gwarif and Mamurah, and asked for permission to attack it. Their BATT commander had hastened to BATT Headquarters and had arranged for all the support necessary; viz. artillery, aircraft, procedures for casualty evacuation, radio frequencies and codes, etc. The BATT commander had then raced back to Mamurah in his Landrover, to organize the departure of the firqat patrol that evening. Incredibly, the firqat commander calmly announced that his men had changed their minds and did not want to go.

Even more serious manifestations of this endemic problem occured during Operation 'Jaguar', mounted in October 1971 with the objective of seizing a permanent and secure base on the jebel. The first major action in this operation was designed to seize an old SAF airstrip known as Lympne, four miles east of Jibjat and located on the gatn between the two great wadis of Arzat and Darbat. A squadron of the SAS, the Baluchi members of the SAF and the firqats A'asifat and Salahadin marched all night to reach the strip on the morning of 2 October. Finally, no more than half of the numbers of the original force stumbled onto the airstrip at 0435 hours and set about making it secure. Fortunately, the adoo were conspicuous by their absence and remained so for the rest of the day and, by the time that they awoke to the fact that a force was establishing itself at Lympne, it was too late. The SOAF were active by then in airlifting reinforcements, which consisted of two companies of the SAF, two 75 $\mathrm{mm}$ guns and the hundred strong firqat Khalid Bin Waalid. However, the airstrip began to break up under the impact of the number of Skyvan aircraft and helicopters utilizing it. Lt Col Watts, therefore decided on the afternoon of the second day to transfer the base 7000 yards west to 
Jibjat, where there was a better landing strip. Accordingly, he ordered a strong BATT detachment, with the three firqats, to clear the route to the new position and to secure it for the main body. At this critical juncture the firqat A'asifat steadfastly refused to move. They claimed that they were tired and had had no food (the lack of food accruing from the fact that they had thrown their rations away on the march to Lympne in order to lighten their loads). In addition they claimed that they had been promised support by 1000 regular troops ('geysh'), were in contrast to the 20-30 BATT personnel who were actually accompanying them. As a result of this mutinous attitude, a reduced force set out. (Jibjat was in fact secured, and the base moved from Lympne).

However, this was not the only example during this particular operation of profound command problems faced by those who sought to direct the firqats. By 9 October the Sultan's forces had clearly secured the area. The enemy had been hunted off the plateau and had withdrawn for shelter into the thick bush of the wadis. The firqat Khalid Bin Waalid were exultant and established themselves with an SAF company in the Bait $M a$ 'asheni heartland at a base nicknamed 'White City' but later re-named by the firqat Medinat Al Haq ('The Place of Truth'). It was at precisely this critical point, when the enemy were shaken and when the successes of the previous week should have been exploited by pursuing the enemy and driving them from their sanctuaries in the wadis, that the firqat A'asifat decided not only once again to prove rebellious, but to infect the firqats Salahadin and Khalid Bin Waalid. Despite dispensations from the Sultan, the three firqats stated that they wished to observe Ramadan (20 October) and were adamant that as far as they were concerned the war had ceased whilst Ramadan was in progress. The Sultan's forces were therefore left with no option but to abandon their key position, for which they had fought so hard and which threatened the principal supply caves in the Wadi Darbat, and to withdraw them north back to Jibjat. With total success so close, it was indeed a bitter pill to swallow, and Lt Col Watts seethed with anger. This anger was certainly not appeased at a meeting that he held with the firqat leaders at Jibjat on 11 October, when the latter demanded more rations as they had burned those that they had in order to avoid having to carry them on the march. Watts was so incensed that he stated flatly that he could see no point in British troops losing their lives in order to help people who did not merit their help, and that he was considering withdrawing BATT personnel entirely and leaving the firqats to their own devices. it was an extremely powerful argument. The firqat leaders fully realized that without the BATT they would be deprived of all their air. artillery, mortar, machine gun and medical support that they now enjoyed. If they were left to depend upon the SAF, it was questionable as to whether the firqats would survive at all for very long. SAF did not have the manpower to support the firqats; the vast majority of SAF has their resources fully extended in organizing and supplying their own Arab and Baluchi companies and had none to spare - in either material or psychological terms - to deal with the firqats who were characterized by incessant demands for more supplies and interminable arguments, both within and between themselves. In any event, even if the SAF had possessed the resources to support the firqats, it is extremely doubtful that they would have had the inclination to do so. The firqata were profoundly mistrusted by the SAF for understandable reasons; the former were charaterized by gross insubordination and indiscipline, as witnessed by Operation Jaguar, whilst the fact that many of the firqat leaders had been former senior officers of the adoo could not have added to their credibility in the eyes of the SAF. Their withdrawel from the theatre of operations at critical junctures must have led many to believe that some firqat leaders had not totally renounced their former loyalties (especially in view of the fact that close tribal affiliations existed between many of the firqat and the enemy). As a heavily armed and lavishly equipped manifestation of tribal seperatism, with an often ambivalent attitude towards the central Government, it is hardly surprising that they were regarded with extreme suspicion in many government quarters.

Not only did the prevailing social structure within the tribal group seriously impede western concepts of military discipline, but tribal seperatism also was frequently a serious problem in this sphere. This particular aspect of the Dhofaris' social structure ensured that co-operation within a firqat by members of different tribes was frequently impossible. An outstanding example of this was the mutiny which virtually destroyed the firqat Salahadin, the very first to be formed. This mutiny occurred at Mirbat on 21 April 1971. The origins lay in a dissension between two of the firqat's senior officers, Qartoob and Mohammed Said, the latter being in command; both - as was commonly the case - former adoo leaders. Qartoob, who had defected to the Sultan's forces 
after they had regained Sudh (cf. below), felt resentment against the authority enjoyed by Mohammed Said. Of even greater significance, however, was the fact that Qartoob was a member of the Bait Umr tribe, based at Mirbat. This tribe was extremely powerful and controlled most of south-eastern Dhofar; and it profoundly offended Qartoob's pride to serve under a member of the Bait Gatun, a minor tribe of the central area of Dhofar. Doubtless he had been taunted by fellow tribesmen within the town itself. Inevitably, factions emerged supporting the rival parties in the dispute based upon tribal divisions. The result was that, at 0700 hours on the next morning, only 68 men were on parade; of these 68,40 decided to fall out and leave the firqat Salahadin; leaving only 28 members of the firqat, almost precisely its original number when the firqat was first formed.

It was these two prominent characteristics of the Dhofar social structure - a profound democratic instinct which was antipathetic to traditional military discipline and tribal separatism - which underlay the PFLOAG's determination to eliminate the tribal structure. The determination with which the Islamic traditionalists resisted these pressures ensured that only terrorist measures by the Communists could overcome this resistance; which, in turn, reacted adversely upon the PFLOAG in so far as it profoundly alienated many of the adoo. In addition to ruthless coercive measures, the PFLOAG/PFLO adopted the familiar Metternichean technique of posting adoo to areas far removed from the geagraphical base of their tribe. The mutiny of the firqat Salahadin spelt the end of the experiment in the multi-tribal firqat.

Ons should not assume, however, that this profound problem of cultural seperatism between the SAS leadership and training cadre and their firqat troops impeded effective leadership by SAS officers and NCO's. Indeed, the irregulars learned from experience that their British mentors would sacrifice their own lives rather than desert their allies. An outstanding example of this was provided on 12 April 1974, when Capt Simon Garthwaite was killed whilst trying to rescue a wounded firqat sodier pinned down by enemy fire. Garthwaite's magnetism both within the SAS and among his firqat followers, was considerable. This fact is attested to by a friend, who stated that at formal mess dinners Garthwaite was uneasy, but felt completely at home in the primitive and hostile terrain of the jebel:
'Boots (no socks), shorts, a belt and his rifle were all that he carried ... He had an astonishing way with local soldiers. They were drawn to him whatever 'the Captain' said, they would gladly do; wherever 'the Captain' went they would follow.' ${ }^{\prime 9}$

The second major problem associated with organization and control of the firqat - compounding the problem of indiscipline - was a marked and increasing tendency among the firqats to demand supportive fire power from the regular army and air force before they would go into action; a process that neutralized their natural advantages of stealth and surprise and the guerrilla techniques to which they were so naturally acclimatized. A startling manifestation of this serious deficiency occured during a firqat offensive in January 1975. In this period the PFLO was being pressed back towards the border with South Yemen, accompanied with growing intensity of conflict and increasing casualties on both sides (cf. below). In a catacomb of limestone caves, almost invincibly protected by a dominating hill, the guerrillas had their main stores of weapons, ammunition and food. This cave complex was situated at Sherishitti, in the vicinity of the coastal town of Rahkyut in the far west of Dhofar. The caves lay in a very strong position at the head of a long wadi extending from south to north and four miles inland. Several sheer escarpments protected them.

It was a natural fortress, the conquest of which demanded speed, stealth and local knowledge. On SAS advice a lightly armed firqat unit was nominated for the task of spearheading a battalion assault. SAS climbers were on hand to assist in the final stages after the caves had been captured; the Regiment's demolition experts were to destroy both the caves and their contents. However, before the firqat could cross the start line to begin the assault, they insisted upon a demonstration of supporting aircraft, artillery and armoured cars, and demanded that this be repeated every few hundred yards during the advance. Inevitably, this orchestrated barrage widely advertised the commencement of the operation; not only was the vital element of surprise lost, but the subsequent ponderous advance provided the rebels with ample time to prepare an excellent defence.

During the ensuing two days, under increasingly accurate enemy machine-gun, rocket and mortar fire, the assault ground to a halt. In a lecture appertaining to this operation Brig (later Maj 
Gen) John Akehurst states how the situation deteriorated:

'In an attempt to capture the caves the advance was ambushed by the enemy as it crossed open ground and the leading company lost 13 killed and 22 wounded in less than an hour. ${ }^{110}$

The first to die, in a carefully prepared ambush, was a British officer who was moving down an exposed forward slope with his company before attempting to gross a gulley. This group was now hit by the full force of well-sited machine guns and mortars located almost immediately above it. Attempts by supporting forces to save the now isolated vanguard attracted more withering fire, and spectacular bravery was displayed by individual officers and SAS troopers to recover the wounded. At dusk on the third day of the operation the SAS squadron moved forward to facilitate the withdrawel of the beleaguered company. Striking back at the rebel positions with accurate machine-gun and rocket fire, they seriously inhibited the enemy's response whilst the remnants of the advance guard fell back. An operation originally conceived to be of 24 hours duration consumed three weeks and, in actual fact, the caves were never occupied by government forces. (This does not imply, however, that the operation was a total failure. Indeed, it was an outstanding success in some respects, but due to other, quite unintended factors. The approaches to the caves were denied to the insurgents by artillery fire. The ridge on which the caves were situated extended southwards to a hillock of huge broken boulders, nicknamed 'Stonehenge'. From this point the SAF could dominate the 'Freedom Road', and the range between 'Stonehenge' and the cave complex was approximately 3500 yards, well within the capability of heavy artillery. Accordingly, two 106 $\mathrm{mm}$ recoilless guns were placed on 'Stonehenge', and spent the ensuing five days firing directly into the caves day and night. During this time a bulldozer was trundled down off the 'gatn' and a track driven through the bush to allow a Saladin armoured car to fire shells directly into the caves' entrances. The $76 \mathrm{~mm}$ shells fired by the armoured cars thenceforward permanently denied access to the caves by the adoo.)

However, it would be wrong to assume that the results of employment of firqats had a totally negative effect. At its best a firqat worked with a speed and efficiency in recovering lost territory unique in Dhofar. Brig (later Maj Gen) John Ake- hurst (Commander, Dhofar Brigade) describes the 'modus operandi' of the firqats in such circumstances ${ }^{11}$ :

'First, the firqat would select a base of their choice. Provided it offered good prospects for land access and drilled water we would mount a largely military operation, perhaps a whole battalion, to capture it. Military engineers would then bulldoze an access track and down the track would come a drill rig.

Troops would then thin out to the minimum necessary to defend the base with firqat assistance. While the drill turned away, the Civil Aid team set up a clinic, a shop (with Government rations, which would be free at first but later sold, though at subsidised prices), a school and a mosque. Engineers would be building a distribution scheme for the water with water-points for humans and troughs for cattle and camels.

All this probably took four weeks. Water is at a premium ... and people throughout the tribal area would bring in their cattle... The civilians, of course, were in regular touch with the enemy, many of whom were their relations. When they came in for water and other Government munificence the firqat talked to them, first to gain intelligence, but second, to tell them to let the enemy know that they should not interfere with the provision of these good things. The enemy themselves were totally dependent on civilian goodwill and therefore were forced not to interfere.

It will be apparent from Maj Gen Akehurst's comments that the entire concept of the firqat was an integral aspect of the SAS's 'modus operandi' in Dhofar; whereby civil aid programmes were an integral aspect of intelligence gathering as the basis for more specifically military operations. It will also be apparent that the firqats were most effectively utilized in the non-military 'politicization' process which features so heavily in insurgency wars. An example of their effectiveness in this context is the occupation of Sudh, a small coastal town 20 miles east of Mirbat that had been abandoned by the SAF in 1969 and was subsequently controlled by an adoo band 50 strong led by famous adoo leader named Qartoob (see above, with regard to the mutiny within the firqat Salahadin). The town was successfully occupied by a force transported by sea on 23 
February 1971, and there was no adoo presence in Sudh when the occupying firqat Salahadin entered the town. The firqat Salahadin succeeded in securing the defection of many members of the adoo in the region (including the leaders Qartoob and Dherdhir) to their ranks, as well as ensuring the allegiance of the townspeople to the Sultan's cause. The tribal affiliations between the firqat and townspeople/adoo had played a major role in the process. No SAF unit would have achieved such results. The vital role performed by the firqats with regard to intelligence gathering operations was made manifest after the conclusion of major hostilities in the Western Area at the end of 1975 (cf. below). Adoo groups remained active in the Eastern Area, despite the fact that this should have been impossible in view of the ceaseless pursuit of SAF and firqat. The fundamental reason why the remaining insurgents could thus survive was the fact that all incoming intelligence regarding their activities deriving from the civil population of the region had ceased. This dearth of intelligence could be attributed to the fact that the SAF now totally controlled the area (the SAS/BATT teams had moved out of the area a year previously), and its commander, possessing the innate distrust of the firqats shared by many SAF personnel, had refused to utilize the firqats in an active role.

Within this context of the positive aspect of firqat operations, it is opposite to discuss the activities of one officer recruited by the Sultan from the SAS force as a freelance, contract firqat leader who maximized the effectiveness of the firqat concept as a COIN weapon. Working under the direction of another SAS veteran who was now in charge of Dhofar's military intelligence, he lived for months on the edge of the Empty Quarters, dressed like his Dhofari warriors and indistinguishable from them. He dropped and collected agents over the border with South Yemen; and, in 1972 decided to blow up the army fort at Sinau, 80 miles inside Yemeni territory. The operation was completely clandestine; to such an extent that had he been taken prisoner he would have been disowned by the Sultan's hierarchy many of whom, including the British Commander-in-Chief, had absolutely no prior knowledge of the operation. With two Bedford trucks carrying $500 \mathrm{lbs}$ of unstable gelignite, and 80 men (including a party of South Yemeni exiles trained in Saudi Arabia), he arrived unimpeded at the fort, where the small garrison surrendered without resistance. Little more than half an hour was needed to plant the gelignite, still in its $5 \mathrm{lb}$ boxes, in each corner of the two-storey stone fort, and to link these with detonator cord to a five-minute safety fuse in the courtyard. Having ensured that the engine of his escape vehicle was safely running, the British firqat leader lit the fuse and effected a rapid exit. The resultant spectacular explosion that occurred just after dusk not only destroyed the fort but also a Yemeni Government shop, garages and a house. The object of this audacious operation was to divert the resources of South Yemeni's army from aiding the guerrillas as these infiltrated into Dhofar farther south, along the coastal plain. (As is so often the case in such episodes, the ultimate consequences were of the nature of an anti-climax. Although the Sultan of Oman was impressed, the British military commanders were horrified, as border crossings are a perennially sensitive issue for the political authorities in Whitehall. The contract officer who led the incursion into the South Yemen transferred to other duties in Dhofar soon afterwards, in command of another firqat. The leadership of his former firqat operating in the Empty Quarter was assumed by an orthodox SAS team, and its cross-border operations ceased).

\section{Non-military dimensions of the conflict:}

It should be borne in mind that the 'hearts and minds' programme formulated by the SAS involved this unit in the specifically non-military aspects of the assault upon the PFLO. Thus, point 1 (a veterinary campaign) involved experimentation in animal husbandry (not always successful, as the improved strains of livestock introduced by the SAS were often infected with diseased strains of indigenous livestock); drilling of wells; and the establishment of a model farm on the outskirts of Salalah. Point 2 (the provision of previously non-existent medical services) involved the SAS medical personnel in supplying the medical requirements of the Dhofaris until trained (or, more often, semi-trained) indigenous inhabitants could assume their duties. Members of the BATT team thus established rudimentary clinics. These services were gradually taken over by the Civil Aid Department (cf. below). However, an example of SAS civic action at a late point in the campaign occurred in a small group of five islands in the Kuria Muria group which are located some 25 miles off the coast opposite Hasik, the next town east from Sudh. Only one island in the group - Al Hallaniyah was populated (83) and in June 1975 a mysterious epidemic struck this island, killing 16 of the population (except one) and the majority of the 
elderly. CAD requested the SAS to despatch a BATT team to the island, which was accordingly done on 23 June 1975. As a result of the efforts of this team - a group of four, all Arabic speakers, under the command of Cpl Wally Warwick the epidemic was extirpated and the health of the villagers was enormously improved by the ample provision of iron, vitamins, anti-biotics and anti-tubercular drugs in tablet and syrup form. Of equal importance, they returned with a full reconnaissance report and recommendations. Warwick stated that only two alternatives were viable; either AL Hallaniyah should be the focus of extensive civil aid development, or the population should be rehabilitated and rehoused on the mainland. The former course was adopted (cf. below).

An important aspect of Point 4 (psychological warfare) was a sophisticated information service. This was largely the fruits of the efforts of $\mathrm{Cpl}$ John Lane, SAS. The dissemination of transistor radios throughout the jebel at low prices, combined with bulletins on notice boards situated at strategic points in the towns (i.e. at every gate through the perimeter wire which surrounded the towns, where packs were inspected for mines and weapons entering, and food and medical supplies leaving; and where queues of people naturally developed). (Transistor radios have been a most powerful instrument for the dissemination of Arab nationalist propaganda, a factor fully appreciated by Nasser). The psychological assault had three principal objectives:- improving the morale of government forces by emphasizing their successes and minimizing their defeats; informing the populace of the new civil development projects which were symptomatic of a new and far more enlightened administration; and the development of an aggressive ideology to counter that of the Marxist insurgents, this new ideology being founded upon the re-assertion of the Moslem religion. The emphasis throughout was on 'white' propaganda (i.e. emphasizing the positive aspects of the Sultan's policies) as opposed to the 'black' variety (i.e. vituperation directed at the enemy.) Radio Aden, predictably, was characterized by 'black' propaganda. Point 3 (intelligence) was the responsibility of an intelligence cell controlled by WO Birrell, assisted by several junior NCO's. This aspect of the COIN offensive naturally gathered momentum as the war progressed and the psychological counter-offensive - combined with the escalating alienation of Dhofaris by the PFLO leadership - yielding constantly increasing numbers of defectors; who, in turn, expanded the knowledge of the intelligence personnel with regard to adoo organization, etc.

\section{Rorke's Drift re-enacted: the Battle of Mirbat}

In July 1972 the SAS experienced its most dramatic confrontation with the insurgents. This confrontation was singularly remarkable for several reasons. First, it was curiously anachronistic within the context of a dead imperial power. being reminiscent of the desperate sieges of embattled garrisons caught in the midst of native uprisings (as occurred on the North West Frontier of India, for example, or Rorke's Drift in South Africa, in the January of 1879). Secondly, a siege situation was totally alien to the traditions of the SAS, whose personnel were never conceived in the role of garrison troops. The scene of the conflict was the town of Mirbat, situated approximately 40 miles from the provincial capital of Salalah; a huddle of flat-topped houses and two ancient mud-walled forts flanked on two sides by the sea. Until the action of July 1972 the town had been characterized for the British who served in this base by a deadly monotony; punctuated by sporadic mortar or anti-tank missiles fire directed at Mirbat by an unseen enemy. Immediately prior to the frontal assault of the Dhofari insurgents, six mortar bombs had struck the town on 28 May, on 6 June a further six, and on 8 June three $75 \mathrm{~mm}$ shells. At this time Mirbat was occupied by a BATT team drawn from the Regiment's B Squadron, under the command of Capt M.J.A. (Mike) Kealy. The other members of the team were:- L/Cpl Pete Wignall; Cpl Roger Chapman; Tpr Labalaba; Tpr Savesaki (Tprs Labalaba and Savesaki were Fijian); Tpr Harris; Tpr Tobin; Cpl Bob Bradshaw and Cpl Reynolds. The training team's functions included the training of the local firqat, the maintenance of vehicles and the implementation of the "hearts and minds' concept through the dispensation of rudimentary medical care for men and animals. In addition to the SAS team the town was occupied by a group of 30 Askaris from Northern Oman, 500 miles distant, armed with accurate but slowfiring .303 rifles (i.e. slow firing in comparison with FN semi-automatic rifles and AK-47s). These served the Sultan's representative (the Wali, or Governor, of the town), as town gatekeepers, searching all who came and went for messages and supplies (including food) that might be destined for the rebels. These Askaris occupied a fort near the water's edge known as the Wali's fort and situated some 100 yards north-east of the HQ of the BATT team (known acronymously as the 'Batt house'). Living within 
the town itself, armed with FN rifles and light machine guns, was the local firqat. Normally its strength was approximately 60 , but at least 20 were somewhere in the mountains on a reconnaissance patrol. (This was the result of a deliberately planned PFLO diversion). Finally, there was a further force of approximately 25 men of the Dhofar Gendarmerie (DG); armed with FN rifles and a single light machine gun, in a second fort just within the wire. In front of this fort was the dug-out position for a veteran $25 \mathrm{pr}$ artillery piece of World War II vintage. The DG fort dominated the town and Mirbat's only airstrip. It was, therefore, a vital position (cf. fig. (i)). In addition to the artillery team, the heaviest weapons available to the SAS team in their Batt house were two machine guns (a .5 in Browning and GPMG General Purpose Machine Gun) and an $81 \mathrm{~mm}$ mortar.

At dawn on 19 July 1972 Mirbat was attacked by a column of 250 adoo, armed with the ubiquitous Kalashnikov AK-47s, light, heavy and medium machine guns, mortars of various calibres up to $82 \mathrm{~mm}$, two $75 \mathrm{~mm}$ recoilless anti-tank rifles and an $84 \mathrm{~mm}$ Gustav rocketlauncher. The column had marched south towards the town and the sea, and then dispersed into carefully organized combat groups, each of approximately 10 men, which spread out in a wide arc around the town. Another group made a circular trek east to the beach and then back again along the coast to penetrate the town from that sector. Thus, when the attack was launched the town was completely isolated and its defenders had no means of escape. Much of the fiercest fighting undertaken by the SAS team was centred on the $25 \mathrm{pr}$ gun pit outside the Wali's fort, which was defended by Capt Kealy and Tprs Tobin, Savesaki and Labalaba (Tpr Labalaba was shot dead in the engagement and Tobin was mortally wounded). The ordeal of Mirbat's defenders was lightened by vigorous air support by the SOAF. who rapidly responded to Kealy's communication to Provincial $\mathrm{HQ}$ at Salalah that Mirbat was under attack, and sent in two waves of Strikemasters. These air strikes undoubtedly relieved pressure upon the fort. From the radio in the artillery bunker, Kealy relayed positions of enemy targets to the Batt house which, in turn, radioed the information back to the Strikemaster pilots.

However, nothing less than substantial reinforcements could retrieve the situation and, by a fortunate circumstance, these were forthcoming. That this was the case vindicates Clausewitz's state- ment that 'war is the province of chance'. Certainly, the relief of Mirbat can be attributed to a remarkable convergence of coincidental factors. The first link in this chain of coincidence was forged by the ironic fact that, on the day of the attack, the nine man BATT team were to fly out and return to England, to be relieved by $G$ Squadron SAS. Before B Squadron could leave the territory, it had to hand over to its successor in Dhofar. The relieving force had arrived from England the previous day and were, in actual fact, already entrenched in the hills surrounding Mirbat. The majority of officers and senior NCO's had been in the advance party and were already taking over positions in the jebel from the outgoing squadron, leaving only the younger soldiers in Salalah. An even more remarkable coincidental factor was that, at $0800 \mathrm{hrs}$ on the morning of the attack, the squadron commander, his sergeant major and 21 soldiers paraded, having originally intended to go to a nearby range to test fire their weapons as part of the normal routine of taking over. They were heavily armed for such a small group; nine GPMGs and four M79 grenade launchers, in addition to their semi-automatic rifles. At this point the action at Mirbat had been in progress for two-and-a-half hours. That the attack was a major one could not be in any doubt. The outgoing squadron commander, Maj Richard Pirie, appreciated that the only manner in which help could reach Mirbat in time was by air, despite the monsoon, and had already moved to the SOAF HQ at Salalah airfield in order to establish a joint operations centre. Thus, the 23 soldiers embarked in three SOAF helicopters at Salalah bound for Mirbat, and landed south-east of the town according to plan. Their arrival at $0915 \mathrm{hrs}$ coincided almost exactly with a second air strike around the fort. The party of SAS reinforcements deployed into two 10-man groups and a command group, and advanced inland towards town. It was almost $1030 \mathrm{hrs}$ before the most seriously wounded - Tprs Tobin and Savesaki and the wounded Omani gunner were evacuated by helicopter.

\section{Aftermath of Mirbat}

By mid-day the adoo had withdrawn. In retrospect, after the war had ended four years later. many considered that the battle of Mirbat had been a decisive turning point. The insurgents had been compelled to launch a spectacular attack to counteract the high propaganda value of the Government's successes during the previous year, in which Operation Jaguar (cf. above) had signalled the successful penetration 
and establishment of a permanent foothold on the formerly sacrosanct (i.e. for the enemy) jebel. The attack on Mirbat had been well planned and well executed. By using the cover of the monsoon, the PFLO had calculated that the SOAF would not be able to fly. Moreover, having decoyed the firqat out on patrol, they had anticipated that 250 hard core fighters, supported by all the Eastern Area's recoilless artillery and mortars, should be more than sufficient to 'take out' all the defences that remained. From the enemy prisoners it was learnt that the adoo objective was to capture the town, to hold it for a few hours only - possibly for a day - to denounce and execute the Wali and his advisers, to subject the townsfolk to a propaganda harangue, and to return once more to the jebel. Had these objectives been fulfilled, the psychological impact upon the Government's COIN offensive would have been disastrous. No other Wali would have been found (in any event it had been extremely difficult to find a governor for the town in the first instance). Townspeople throughout the province would have been terrified into total non-cooperation with the Government forces and the PFLO would have gained total control over the coastal towns. In the event, three major factors were instrumental in destroying these plans. The first was the skill and tenacity of the SAS BATT team and the impeccable judgement of its commander throughout the assault. The second was the skill and courage of the SOAF pilots. The third was the remarkable coincidental factor that Capt Kealy's team was to leave Mirbat on the very day of the attack and, accordingly, the relieving SAS squadron was close by, on hand to provide reinforcements. The retreating adoo left approximately 30 bodies behind and approximately 10 wounded, who were taken prisoner. However, their sources later admitted that the toll incurred by them had, in fact, been considerably higher (approximately 100). The SAS casualties had been two dead and two seriously wounded; the Dhofar Gendarmerie lost one man killed and one wounded, and the Oman Artillery one dead. The PFLO defeat at Mirbat had three major repurcussions. First, in view of the heavy casualties they suffered, it was considered that the PFLO were never able to deploy similar concentrated forces to mount attacks of the same scale and intensity elsewhere. From the psychological aspect, the adoo had clearly lost credibility in a warrior society through decisive defeat in open combat, where the odds were heavily in their favour. Thirdly, the PFLO defeat at Mirbat invoked serious political repercussions for the insurgent cause. The faith of the younger fighters in their leaders had been shattered. The latter resorted to a terror campaign in an effort to reassert their authority, and a number of 'kangaroo' courts were established to 'judge' and execute those considered responsible for the failure of the plan. The reaction to this terror campaign, combined with the impact upon morale created by such heavy casualties, intensified the divisions within the ranks of the adoo. It was hardly surprising, therefore, that August and September 1972 were characterized by a noticeable increase in the number of insurgents surrendering to government forces.

\section{The situation in 1975}

It was stated above that 1975 was the decisive year in the COIN operations within Oman. However, in order to assess the importance of the military operations undertaken in this year, it is extremely important to provide an appreciation of the COIN situation immediately prior to 1975 , in order that these operations can be viewed in their correct perspective. This appreciation can be categorized under the headings of military and political dimensions.

\section{The Military Dimension:}

A major development that characterized the years 1972-1975 was the creation of 'cordon sanitaires'. The object of these barriers was the interruption of enemy supplies which were despatched regularly from PDRY by animal train and routed through the jebel. In 1972 a 35 mile wire and mine obstacle, termed the 'Hornbeam Line', was constructed across the enemy supply routes into Central and Eastern Dhofar. The Hornbeam Line could not, of course, totally repel human infiltration but it undoubtedly became a most effective barrier to animal trains; and as such it soon exercised an important impact upon adoo morale and capability in Eastern Dhofar. The adoo also suffered a crippling shortage of supplies and the restriction on their movements seriously hampered the provision of reinforcements and the evacuation of wounded. The Hornbeam Line had its ancester in the form of the 'Leopard' Line, which was established after the successful incursions by Government forces into the jebel signalled by Operation Jaguar (1971) (cf. above). ON 2 November 1971 the first of three positions was established at a point where the mountains narrowed between the western end of the plateau and the beginning of the great stark jebels and wadis of the Western 
Area. These positions were withdrawn in the summer of 1972 as they could not be supplied during the monsoon season. However, to reiterate, it was succeeded by the Hornbeam Line, which extended from Musgayl on the coast for 40 miles inland to a position named 'Oven'. The Hornbeam Line was supported by the Hammer Line (established in 1973), which occupied similar positions to those of the Leopard Line. In 1973 the (then) Shah of Iran, mindful of the Communist threat to the Gulf, sent a well equipped battalion task force to Oman, which cleared the track from Salalah to Thumrait, permitting the route's development into a tarred road. In 1974 this force was increased to a brigade group complete with ample helicopter support, providing the Sultan with sufficient strength to move into a highly geared offensive. It was decided to establish a second major obstacle, similar in nature and intention to the Hornbeam Line, extending inland from approximately half-way between the Hornbeam Line and the PDRY border. In this sector the three line was closer to the coast and the enemy supply lines were thus constricted into a more confined area. The obstacle could, therefore, be shorter and more effective. In a period of intensive operations during December 1974 - January 1975 the Iranian Brigade, assisted by the SAF, fought its way south to the coastal region of Western Dhofar, in striking distance of PDRY's border. The second major 'cordon sanitaire' - designated the 'Damavand Line' (after the principal mountain range of Iran) - was based upon these newly won positions.

These lines would have been familiar to Kitchener, as they corresponded in conception to the blockhouse system which he initiated during the Second South African War of 1899-1902. The Hornbeam and Damavand Lines (cf. fig (ii)) consisted of heavily entrenched defensive positions placed at several thousand yards distance along barbed wire defences which were booby trapped and mined. The Damavand Line consisted of a triple concertina fence windlassed between angle irons and booby trapped, then a minefield and then on the home side a simple fence to repel cattle and humans. The Hornbeam Line was less elaborate, but followed the basic pattern of minefields/barbed wire perimeters/defensive positions. It should be emphasized that these barriers were not simply passive lines of defence. The effectiveness of these barriers depended upon constant patrolling, to ensure that the enemy did not create gaps. On one occasion (in mid-1975) a patrol was ambushed amidst enemy mines where, because the monsoon prevented enemy evacuation, the wounded were subjected to a 14-hour man carry; not surprisingly, some of the casualties died. The task of patrolling could not be assisted by helicopters. Although they were extremely valuable in the engagement of specific targets, they were of little value in search and destroy missions when, in the thickly wooded terrain, enemy presence was first manifested by a burst of machine-gun fire through the floor. Moreover, these roving missions sometimes resulted in hazardous rescue operations for shot-down pilots, perhaps involving further loss. For these reasons they were discouraged. There can be little doubt that the adoo suffered from the constricting pressure of the government forces as the latter expanded their operations between the 'cordon sanitaires', upon which they were securely based in terms of communications and supplies. The effect upon insurgent supply routes was particularly deleterious. This escalating pressure was manifested in the declining numbers of adoo. At the height of the insurgency, in 1970, the enemy could muster 2000 hard core guerrillas and 3000 militia, the latter operating part-time and being virtually indistinguishable from guerrillas. However, at the outset of 1975 it was estimated that there were now some 850 hard core insurgents remaining within Dhofar, 250 being east fo the Hornbeam Line. In an attempt to throttle enemy supplies near source, a battalion had been established in 1972 at Sarfait (sometimes referred to as Simba). However, the nature of the ground - a series of sheer escarpments graduating down some $4000 \mathrm{ft}$ to the sea - combined with the enemy strength thwarted this intention. The battalion remained beleagured and dependent upon air re-supply, but it absorbed a great deal of enemy attention and, as subsequent event unfolded, was essential to the final collapse of the enemy.

It was evident that the war was far from over. The Western Area contained numerous and extensive caches fo adoo weapons and stores and was regarded by him as his home base, to be fought for yard by yard. To fully exploit the great advantages of the new base of the Damavand Line would take a great deal of effort in very difficult country, and the enemy were unlikely to remain passive supine spectators whilst this effort was being undertaken. Nevertheless, the contrast with the situation prevailing in 1970 was remarkable. That the situation had been redressed to such an extent was due in no small measure to the joint efforts of the SAS/SOAF/SAF (particularly in the years preceding 1973, when 
there were no substantial reinforcements available from external sources). These efforts crystallized in the gradual but relentless penetration of the jebel from the Eastern Area, climaxed in 1971 by Operation Jaguar. The process of penetration had been initiated on 13 March 1971, prior to Jaguar, when a position known as 'Eagle's Nest' was taken. This position was within a night's march from Mirbat, and was located at the extreme eastern end of the escarpment. (The position was eventually abandoned due to the inability to provide an adequate supply of water to support a permanent foothold on the jebel; a prospective site at Tawi Atair proving inadequate for this purpose). Moreover, the SAF had witnessed a considerable expansion and, by 1973 , had developed into a well-equipped, well balanced force of two large brigades, an air force of some 80 aircraft (three squadrons of strike, helicopter and transport aircraft), and a small navy capable of controlling territorial waters. Approximately half of this force (Dhofar Brigade) was involved in Dhofar; the remainder being based in north Oman resting, recruiting and retraining or in supporting roles. Dhofar Brigade, eventually based on five battalions with supporting arms and services, was responsible for the conduct of operations except in a comparatively small area allocated to an Iranian Brigade (cf. above and fig. (ii)).

In 1975 the SAF had a strength of approximately 12000 , and possessed artillery batteries (trained by a small unit of British advisers from the Royal Artillery (RA) and known as 'Cracker Battery') and an armoured car squadron. As in 1958 its overall commander was a seconded officer in the British Army, Maj Gen K. Perkins (who held this position 1975-1977). (The Commander of the SAF had been up-graded from Brigadier to Major General; all the responsibilities formerly split between Force Commander and Defence Secretary (the latter position occupied by Col Pat Waterfield between 1958 - when Col David Smiley assumed the rank of Chief of Staff of the SAF ${ }^{12}$ - and 1969, when the former retired) being re-united in the Commander of the SAF Maj Gen Tim Creasey assumed this role in 1972-1975, succeeding Brig (later Maj Gen) John Graham (who held the position 1970-1972). The expansion of SAF since 1970 had been dramatic. Two new regiments (Desert and Jebel) had been raised. In 1970 there had been only 40 regular (i.e. seconded from British units) officers serving with the SAF, but by 1977 the number had increased to 200 . The number of contract officers employed directly by the Sultan had similarly increased. The SOAF was commanded by a Wing Commander seconded from the RAF and flown and maintained by seconded and contract officers and airmen. A modern airport had been built at Sib whilst Muttrah, Oman's principal airport, was rapidly modernized.

\section{The Political Dimension:}

During the years 1970-1975 four major factors characterized the political dimension. These were:- increasing divisions within the ranks of the PFLO; the extent to which the Front was increasingly alienating the civil population; the success of the Government's policy of civil development; and the success of the Government's new emphasis upon information services. All four factors were dealt with in an enemy document captured in 1971, containing the observations written by the First Political Commissar of the $\mathrm{HO}$ Chi Minh Unit of the Central Area. He had attended the Third National Conference of the Front held at Rahkyut in the Western Area in the June of 1971 , together with 74 other senior PFLO officers. The document was a remarkably honest attempt, uncharacteristically free of political diatribe, to assess the malaise within the Front's performance, and to rectify it. The document made clear that, underlying this malaise, were the four corrosive developments cited above. First, with regard to internal divisions, a number of ex-regular soldiers who had deserted from the Trucial Oman Scouts and the Gulf armies had now returned from their courses in China and the Soviet Union and were making their presence felt; particularly with regard to their criticism of lack of professional military standards within the adoo ranks. They particularly criticized:- the lack of discussion or any form of de-briefing after battle, so that lessons were never learnt and the same mistakes were repeated; lack of weapons discipline, manifested in the manner in which ammunition was lavishly and uselessly expended, particularly at aircraft flying hopelessly out of range; the fact that commanders did not insist upon sufficient reconnaissance to enable them to arrive at accurate estimates of SAF strengths; liaison between units (although this defect was being remedied by the provision of a radio set to every adoo unit); lack of technical knowledge on the part of many adoo fighters; and far better materials for personal equipment (e.g. ammunition pouches, belts, etc.) Indeed, an air of suspicion and hostility permeates the entire document with regard to attitudes towards the several different components of the adoo. This tension did not apply only to the more pro- 
fessional and more 'amateurish' members of the hard core fighting units. The document pointed to the militia as being particularly unreliable and requiring more indoctrination. It is of interest to note that the documents comment upon a feature which has characterized insurgent movements throughout the world; viz. the dedication of female members to the insurgent cause. The Commissar states that women were more readily converted than men (which is, perhaps, hardly surprising, in view of the subjugation which traditional Islamic society imposed upon their womenfolk, in contrast to which the Front's promise of complete equality for women in the new political dispensation must have appeared particularly appealing). It was recorded that the monthly payments to 'martyrs' widows was to be increased. (Fighters did not at that time receive any payment - a major reason why the firqats were so much more attractive to the tribesmen but their widows did receive an allowance).

With regard to alienation of non-combatants, the Front clearly realized that it had estranged the civil population, particularly in the Eastern Area, and decided to announce a six-months amnesty for any firqatmen who wished to return. The 'people's courts', which had acquired a noxious reputation for 'judgement' and execution without trial, were to be disbanded and replaced by a new court to consist of elements of the People's Army, the Militia and civilians. (The People's Liberation Army - PLA - were the strictly military components of the insurgent forces; the PFLO constituting the political organization and leadership). The revised courts would contain between seven and 11 members, and new, more 'liberal' punishments were devised. (In the past, the vast majority of those who appeared before a people's court were simply shot). The document further admitted that the Front was unpopular in the west also.

The Government's civil development policy was discussed also, as well as the BATT's civil action teams. It was decided that the standard of medical training amongst the adoo units should be improved in order that they could provide medical assistance to civilians; a tacit admission that the Front was being adversely compared, in the eyes of the civilian population, with the SAS and Government forces in this respect. (In actual fact, the standard of adoo medical orderlies was abysmally low. If a wounded adoo could manage to reach Hauf, just across the border in PDRY and many of them made incredible journeys across the mountains, often of several days du- ration that would have killed most Europeans he had a good chance of survival; otherwise his chances were slight. A cave at Sherishitti contained the main adoo hospital in the Western Area; where a Lebanese woman doctor cared for the less seriously wounded; but those whose wounds or sickness were of a more serious nature had to go to Hauf, where her husband was practicing, or were even evacuated from Hauf by ship to Aden). The new Government schools in Mirbat and Taqa (also known as Tarqa) provided a statement of intent from the Front to improve the literacy of the jebel, although it was not stated how this was to be achieved; again a tacit admission fo the Government's educational programme.

Finally, the paper included a particularly revealing statement pointing to the success of the Government's information services. It stated that freedom of religion was a necessity. This represented a major change in Front policy, and derived from the success of the information services of the Sultan's Government in driving a wedge between Islam and Communism.

None of the above factors eroding the effectiveness of the PFLO diminished in the succeeding four years. The numbers of firqatmen seeking amnesty by a return to the insurgents remained negligible. (Observation posts of the enemy were never less than three men strong lest one man should persuade the others to desert with him; thereby testifying to the fact that the PFLO's cause never increased its attractiveness and credibility after it had ruthlessly destroyed the former DLF leadership in 1970; cf. above). Moreover, the Government's civil development programme, which exercised such an adverse effect upon the Front's political impetus, gathered increasing momentum in the succeeding four years. Within this context, it is important to bear in mind that the civic and military dimensions of the COIN assault clearly interacted. It would have been neither possible nor desirable to attempt a re-settlement of the nomadic peoples accustomed for centuries to constant movement in search of grazing and water; yet for development there needed to be a pattern of governmental activity and centres of contact with the civil population. With this overriding objective in mind, military successes - particularly in securing permanent bases on the jebel, upon which the establishment of 'cordon sanitaires' were founded - were immediately followed by the construction of access tracks and by the provision of well-drilling equipment. The wells be- 
came focus points for the population and were consolidated as government centres by the construction of clinics, schools and government shops. By 1974 there was a substantial number of imported teachers, doctors and nurses Egyptian, Lebanese and Jordanian - and this had considerably improved medical and educational facilities. Precisely because civil aid was not keeping pace with military penetration of the jebel (largely due to the remoteness and limited resources of Government ministries in the remote north), a new department, designated the Civil Aid Department, was established in 1973, commanded by an ex-Gurkha, ex-SAF officer, Martin Robb, and intended to implement short term projects until proper civil development projects could be established. The Civil Aid Department (CAD) performed miracles of improvisation. For example, it undertook the production of pre-fabricated buildings which were flown into position on the jebel and then re-constructed to provide a school, clinic and shop. As a result of an SAS BATT team's report regarding conditions on Al Hallaniyah, within the Kuria Murias island group (cf. below), a new site for water was found near the village on the island, a proper well constructed, and a regular Flying Doctor service established; as a result of this last mentioned development Al Hallaniyah, like 37 other Government centres, received a weekly visit. Moreover, a Land Rover was flown in to relieve the sole donkey on the island of the laborious duty of transporting water from the island's only hitherto existing well. However, CAD had its genesis in the civic action responsibilities of the SAS BATT teams; especially in the provision of hitherto unknown medical facilities.

\section{5: The Year of Decision}

\section{Plans and Deceptions:}

Dhofar Brigade was deployed with its centre of gravity in the central and eastern areas. Extended across the jebel from the Hornbeam Line to Mirbat were three battalions supplemented by a reserve battalion and well supported by armoured cars and artillery. The Iranian Brigade of two battalions with artillery were centred on some dominating features between Rakhyut and the edge of the tree line some eight miles inland (cf. fig. (iii)). The enemy HQ and elements of their 9th June Regiment (named after the anniversary of the Dhofar rebellion) had settled in the Wadi Ashoq, a deep winding ravine in the mountainous country between the Hornbeam and Dama- vand Lines. During the final week of February 1975 two battalions routed the enemy and destroyed the $\mathrm{HQ}$; in the process rebuilding morale which had become somewhat frayed during the fighting of January 1975. It was necessary to secure the important heights above the wadi and the piqueting alone might well have absorbed a full brigade. However, by appreciation of the effects of convex and concave slopes and the skilful use of helicopters, units of the SAF (the Desert Regiment, Jebel Regiment and Southern Regiment) cleared both the heights and the wadi. The former, consisting of limestone rocks scoured by centuries of wind into natural weapon emplacements, were ideal natural defensive positions (they could not have been bettered by man-made designs) and were only secured after several well co-ordinated set piece attacks involving all arms and fighter ground strikes in support of well led infantry.

To release infantry battalions for more aggressive operations, the Oman Gendarmerie had been transfered from Northern Oman to garrison the road from Salalah to Thumrait. They were succeeded by a Jordanian unit (91 Special Forces Battalion) which held the road between February and September 1975. Jordan had provided instructors in the north. The Jordanian unit was a well trained, aggressive and experienced unit. In addition, Jordan also sent an engineer company to Oman, which remained until the end of the war and undertook a variety of civil and military tasks, as well as pilots (cf. below).

By June/July 1975 it was apparent that the Damavand Line had sharply reduced the amount of supplies reaching Central and Eastern Dhofar; and it was a reasonable assumption that the enemy pressured between the Hornbeam and Damavand Lines would 'wither on the vine', having had their supply routes cut. Thus, final victory depended upon the clearance of the area between the Damavand Line and the PDRY border. The first option which presented itself, and the most attractive, was to deploy to Sarfait in strength and establish a further barrier there, thereby repeating the success of the Damavand Line and denying the enemy the ability to resupply anywhere in Dhofar. However, there were serious disadvantages attached to such a plan. Some logistic hazards were involved, in so far as troops would be dependent upon helicopter resupply. Of even greater significance, however, were the political risks involved, as the Sultan's forces would be inviting retaliation from regular PDRY forces; the latter, moreover, would be op- 
erating close to their home bases, whilst the former would be placed at the end of a tenous logistical link with its terminal vulnerable to concentrated artillery fire. Further, there would still be a guerrilla campaign being waged in the rear of the Governement forces. The only viable alternative was to establish a third obstacle, just beyond the range of PDRY artillery, extending north from Dhalqut and to clear the country up to this line before advancing to the border. On political grounds this second course, albeit more pedestrian, was preferred. D-Day was chosen as 21 October 1975, a month after the expected end of the monsoon, in order to allow the replenishment of supplies and the withering of at least some of the luxuriant vegetation resulting from the monsoon, which would greatly assist the enemy in defence. A further factor in the choice of date was that it would allow the troops to celebrate the Arab feast of Eid, which ends the month of daylight fasting during Ramadan before being committed to battle. (The problems caused by the insistence of certain firqats in celebrating Ramadan during a critical juncture of Operation Jaguar in 1971 will be racalled; cf. above). The postmonsoon plan envisaged the following sequence of events (cf. fig. (iii)):

(i) Between July and mid-October the driving of a road westwards as far as Defar, with the intention of both a logistic build up and deceiving the enemy into thinking that the real objective was the Sherishitti area.

(ii) On D-Day minus six and four, diversions by Dhofar Brigade at Sarfait and the Iranian Brigade on the coast south of Sherishitti.

(iii) On D-Day a land approach from Defa, initially west to Furious and then swinging south to the high ground overlooking the formidable Wadi Sayq. On D-Day plus one a helicopter assault across the wadi followed within two days by exploitation south to Dhalqut.

These operations would involve a drastic thinning of troops in the centre and east, but it was considered that the prize compensated for the risk, It was considered that by Christmas the Sultan's forces would have cleared the area between Damavand and the new line and would be well placed to advance towards the border, where it was planned to arrive in strength by mid1976.

\section{Operation Badree:}

On 14 August Operation 'Badree', to secure the region through which the new road to Defa would pass, began. An operation designated 'Waagin Badree' commenced at an earlier date as a deception. ('Badree' is Arabic for 'early', and 'Waagin Badree' for 'very early'; this suggestive connotation inbuilt into the operation's code name was a deliberate deception tactic). The lack of immediate reaction to either operation was a pointer to the fact that, although a guerrilla force is highly mobile tactically, it is usually slow to react at a strategic level. Badree drove parallel to the coast, north of the tree line and monsoon area. It ran through areas liberally sprinkled with unchartered anti-personnel mines from the previous December and January operations, and an armoured bulldozer was invariably in the van. The road construction relied heavily upon civilian labourers, who downed tools under fire, but resources were re-grouped and under the direction of the senior adminstrative officer, Lt Col lan Sprackfield, the work was completed within the margin of time prescribed (although narrowly). There were a number of sharp engangements also, in which RPG7 missiles were in evidence. Operation Badree tempted the enemy into the premature use of SAM-7 missiles, when a Strikemaster was shot down and Flt Lt Roger Furlong, a seconded pilot, successfully ejected and was rescued. Thus, SOAF were allowed time in which to revise their ground strike tactics before the crucial D-Day.

\section{Preparations for D-Day:}

PFLO was now virtually unable to influence events east of the Damavand Line. In the absence of extensive supplies of ammunition heavy weapons had been cached and the remaining adoo were mainly concerned with survival. In contrast, in the west the tempo of enemy activity had intensified, with Dhofar Brigade and Iranian positions coming under increasing fire. Three companies of PDRY regulars were operating between Sarfait and Sherishitti, and PDRY $85 \mathrm{~mm}$ had, from their sanctuary west of the border near Hauf, joined in the bombardment of Sarfait. To reiterate, the plan of operations had been largely determined by the intention to avoid contact with PDRY regular forces; yet this factor was now being negated by PDRY itself. As a precautionary measure, Dhofar Brigade was ordered to deploy 5,5 in guns at Sarfait, in order that the PDRY $85 \mathrm{~mm}$ guns could be matched for range. These 5,5 in guns were transported to Sarfait by Iranian Chinook helicopters. The immense logistic activity clearly pointed to an SAF offensive at the end of the monsoon; all that could be done was to conceal the area in which the blow would 
fall and persuade the enemy to extend his resources. This was attempted by avoidance of any preparatory bombardment of the intended objective; threatening gestures from Defar; building new observation posts at Sarfait; and diversionary attacks. It was subsequently learned from surrendered enemy personnel that the adoo had considered the objectives of the Sultan's forces to be in the Sherishitti area and had not discerned their intentions concerning the Dhalqut line.

SOAF had meanwhile greatly increased its striking power by the formation of a Hunter squadron. The aircraft had been acquired from Jordan and the pilots were a mixture of seconded RAF, Royal Jordanian Air Force and contract personnel. The squadron base at Thumrait was at this time no more than a concrete strip, a single hangar with no doors and a number of contractors' buildings. The service and arming of the aircraft was, as in the case of all SOAF operations, the responsibility of a civilian firm, Airwork. The air force commander, Air Commodore Erik Bennett, performed prodigies of improvisation with meagre resources, ably assisted by a seconded squadron leader, Robin Renton. The development of this squadron into a first class fighting unit involved a return to a less sophisticated environment than is commonly associated with modern aviation; and it was not unusual in the hectic months that followed to see pilots towing bombs from the magazines and assiting in the re-arming of their own aircraft between sorties.

As D-Day approached, doubts arose in the helicopter squadron with regard to the coup de main' across the Wadi Sayq. This involved a first lift of two parallel streams, each of six helicopters, which would be overtaken in flight by Hunters tasked to bomb and strafe the landing zone, whilst artillery and armoured car fire neutralized flanking areas. The helicopters, AB 205s, were equipped with exhaust shields to repel the heat seeking SAM-7s, but these certainly did not guarantee immunity. Low flying was therefore necessary to minimize exposure to SAM-7s but this, in turn, subjected the aircraft to further risk from another direction; they would be flying within range of AK- 47 automatic rifles and Sphargin heavy machine guns. The majority of helicopter pilots were contract personnel and some had had as much as six years operational flying; pilots suspected that they were living on borrowed time but under the leadership of W/Cdr Alan Hastings, the SOAF station commander at Salalah, good morale was maintained.

\section{Change of plan:}

However, in the event the projected plan for the capture of the region south of Dhalqut was never executed. Instead Sarfait, much further to the west and far closer to the PDRY border, became the centre of operations. Sarfait had been taken over by units of the Muscat Regiment in May. The Commanding Officer of the garrison, Lt Col Ian Christie. Bored and frustrated with merely observing the enemy held stronghold below Sarfait, the garrison successfully ambushed enemy supply trails in May and June. This involved descending a precipitous $600 \mathrm{ft}$ scarp, negotiating enemy minefields by night and remaining concealed by day. C Cy, Muscat Regiment, had an important role to play in the planned operations.

This was that of staging a large diversion by intensifying these activities once the monsoon was over. Accordingly, on 14 October, after last light, C Cy, led by Maj lan Gordon (a former Gurkha officer and now a contract officer) descended from Sarfait. In the van of the advance was an engineer troop led by Capt Ted Wells, who had spent the previous night hand-clearing a route through enemy mines. In a brilliant operation, repeating on a larger scale the ambushes of four months previously, C Cy seized a prominent feature called 'Capstan', which had long taunted the battalion at Sarfait. At Capstan the company sat in caves and hastily constructed sangers (i.e. circles of rock built for protection when it is not possible to dig trenches) to await the considerable enemy reaction which it was expected would follow. Virtually none came, the enemy having apparently ignored this diversion. In the absence of any resistance, Christie decided to reinforce success by deploying more companies through Capstan down to the sea. This deployment had been completed by 15 October. Almost before anyone had realized it, Christie had created a new line of positions, admittedly not yet linked by wire and mines, but nevertheless capable of making it a very bloody affair for the adoo to try to move through the line in either direction. In effect, the operation planned for two days later - D-Day minus 4 (diversions by Dhofar Brigade at Sarfait) - was rendered completely superflous. Indeed, the unexpected success of the operation originally planned as a diversionary movement from Sarfait meant that there was little point in withdrawing the positions Christie had achieved simply to establish another line further east. Accordingly, on the night of 16 October Maj Gen Perkins and Brig Akehurst decided to abandon the former plan of operations and transfer the main theatre of operations to 
Sarfait. It should be borne in mind that at this point in time the position of Sarfait itself was far from being secure. Whereas in July and August less thatn 30 shells had been fired at Sarfait, in October this figure had increased to over 1000 ; and on 16 October the artillery bombardment had become even more intense, as the enemy no doubt realized that Sarfait was the new base of a line which had effectively isolated the insurgents within Dhofar.

\section{The Climax}

Important areas of doubt concerning the viability of this 'modus operandi' remained. The two most serious problems were the questionable ability of the helicopter squadron to maintain the force thus far forwards and the threat fo PDRY artillery near Hauf, which might conceivably prevent consolidation of Government forces in this area. With regard to this latter factor, for some months the Government had been exerting political pressure upon the SAF to retaliate against the PDRY because of the latter's continued and active support for the PFLO. Maj Gen Perkins, however, had resisted on both political and military grounds; in the former case because he wished to limit the conflict (although one suspects that he was here following the policy dictates of Her Majesty's Government, his ultimate authority) and in the latter because he was doubtful of the ability of aircraft, even when flown by highly skilled and experienced pilots, to destroy wellconcealed artillery emplacements in the difficult terrain. However, PDRY had itself widened the conflict by increasing the artillery bombardment, and the political reasons in favour of retaliation now outweighed those opposed to such a course. Moreover, the interests of morale demanded a vigorous military response. It was, therefore, decided that at first light on 17 October the Hunter squadron, which had been tasked to support the Iranian diversion on D-Day minus 4 , would be re-directed to military targets in the direction of Hauf, and the 5,5, in and 25-pr guns on Sarfait were ordered to harrass these targets between air attacks. To assist in the increased logistic task a naval coaster was ordered to operate off Sarfait as a re-supply point for helicopters. (Capt Philip Brook-Popham was commander of naval operations).

Brig Akehurst placed Lt Col lan Christie in immediate command of the thrust to the sea. Under the latter were a hastily assorted collection of companies from his own battalion, the Frontier Force and the Southern Regiment. By first light the following morning - 17 October - he had gained all his objectives and was dug in. Hauf lay under a pall of smoke and the enemy showed no inclination to inetervene. With this successful consolidation of forces south of Sarfait the fate of the PFLO in Dhofar was sealed. The enemy were now sealed between the Government forces in the east - firmly based on the Damavand Line and those of the west, securely based at Sarfait and its line to the coast. In order to maintain maximum pressure upon the enemy, the Iranian diversion as originally planned was executed. The Iranians had increased their brigade strength by a battalion group and volunteered naval and logistic support. Preceded by bombardment by three Iranian frigates and air attack by Strikemasters, half a battalion flew in to seize a feature on the coast south of Sherishitti. The operation attracted heavy opposition and casualties were immediately incurred in close-quarter fighting around the objective. With determination they dug in, supported by the courageous action of an SAF forward observation party under Capt Gordon Allen who, having been dropped by their helicopter as it traversed the position under fire, were responsible for the co-operation of an artillery, air and naval fire plan. The enemy recognized that seizure of Sherishitti would clearly destroy their last major source of re-supply, and for several days the object of the Iranians' attack was subject to heavy artillery fire, rendering all movement above ground extremely hazardous. One week later the Frontier Force was sent into action, and in the ensuing three weeks to 18 November, under the determined leadership of Lt Col Jonathan Salusbury-Trelawney ( a seconded officer from the Coldstream Guards) this force cleared the enemy north of the Wadi Sayq and finally captured Sherishitti, with its enormous stores of arms and ammunition. In the last week of November Muscat Regiment pushed eastwards from Sarfait, leaving only the Darra Ridge, a large feature extending along the coast inland from Dhalqut, to be cleared.

\section{The end:}

On 17 October Hauf was subjected to extremely heavy air attack. It covered all known military targets as well as the PFLO HQ. It had involved six Hunters with bombs and rockets just after first light and a further strike of four aircraft in the early afternoon. Attacks were continued over the succeeding five weeks, but the enemy made good their losses and, reinforced by $122 \mathrm{~mm}$ and $130 \mathrm{~mm}$ guns, continued to fire at Sarfait 
and the positions around Sherishitti. They introduced fire and movement and became adept at utilizing mountainous terrain for concealment and protection. To this extent, Maj Gen Perkins's misgivings concerning the military aspects of assaults upon Hauf and its defences (cf. above) appeared justified. The anti-aircraft defences accounted for two Hunter aircraft and damaged several others. Nevertheless, combined with the infantry assaults and eventual capture of Sherishitti, these air attacks led PDRY to re-consider its unreserved support for the PFLO. The air strikes were discontinued on 21 November, and several weeks after this the PDRY artillery fire became minimal. By late November it was apparent that those hard core enemy who had neither been killed nor surrendered ( 91 had surrendered in November, five times the previous monthly average for 1975) had either fled to PDRY or simply abandoned the fight. Dhalqut was the last village in Dhofar to be re-captured on 2 December, and this is the official date for the end of the war; the Darra ridge was confirmed clear of the enemy on 8 December and on 11 december the Sultan declared war to be officially over.

\section{Conclusion:}

The second Omani war presented the dual aspects of both a conventional war and a protracted COIN operation. Clearly, the operations of 1975 represented the orthodox military pattern of clearly defined assaults upon specific targets, whilst the operations of 1970-1974 embodied the COIN dimension of the conflict. The two aspects are, to reiterate, closely related; in so far as the concerted attacks of 1975 would have been impossible without the COIN approaches of the preceding four years, which had secured the Eastern Area of Dhofar for Government forces, thereby eliminating the problem of a guerrilla offensive in their rear whilst the conventional advance to the west was in progress. As has also been intimated above, the end of conventional operations did not necessarily imply the cessation of all guerrilla activity in the east, which continued until 1976 (although, pincered between the firmly established Government forces in the east and west, based on their impenetrable defensive lines, it was inevitable that the insurgent forces would 'wither on the vine', as actually occurred in 1976). In February 1976 BATT teams returned to the Eastern Area, and Akehurst issued an unequivocal order to SAF units that all operations would be accompanied by firqat/SAS. As a result, intelligence began to flow once again. Ironically, the very area in which the adoo were most active was the most easterly, on the rocky terrain between Tawi Atair and Eagle's Nest where BATT and the firqats had executed their very first operation on the jebel (cf. above). It had been by-passed and left virtually untouched by SAF and Government civil reconstruction projects as operations extended gradually westwards. In the west the guns of the PDRY ceased their shelling on 5 March 1976 and the PFLO halted its own bombardment on 30 April. The firqats, now numbering some 2500 men, were placed under the control of the government of Dhofar. (These firqats sought to become separatist power bases founded on tribal groupings, but their faction fighting rendered them effectively impotent within a few years). The last SAS squadron finally left Dhofar permanently in September 1976, after an uninterrupted presence in the theatre of six years. During this period, its strength had never exceeded that of a squadron (approximately 80 personnel). Its casualties - 12 dead - were relatively heavy in proportion to its overall strength. In so far as adoo activity continued into 1976, necessitating the continued presence of SAS and firqat teams, 1976 and not the official date of 2 December 1975 is ragarded as the terminal point of this second Omani war. Precisely because of its dual COIN-conventional aspect, the lessons derived from the Dhofar war are peculiar to each individual dimension of warfare, as well as being common to both. They are thus both extensive and complex and, to do them justice, detailed discussion is reserved for a succeeding, final paper (Section B).

- S. Monick, BA (Hons), PhD, ALA

\section{Bibliography: sources referred to in the text}

(1) Part 1 was published in militaria 12/3, October 1982.

(2) Monick, S. The Five-Act Tradegy: the French in Indo-China, 1946-1954. Militaria 11/2, June 1981, pp 1-12.

(3) Ibid. item (1) above.

(4) Quoted by Geraghty, Tony. Who Dares Wins: The Story of the SAS 1950-1980. London: Fontana, 1981, p 157. (Originally published London: Arms and Armour Press, 1980).

(5) Ibid. item (1) above.

(6) Lunt, James. Imperial Sunset: Frontier Soldiering in the 20th Century. London: Macdonald, 1981.

(7) Ibid. item (6) above, p 144

(8) Jeapes, Tony. SAS Operation Oman. London: William Kimber, 1980.

(9) Ibid. item (4) above, p 172

(10) Ibid. item (4) above, p 175.

(11) Ibid. item (4) above, p 174.

(12) Ibid. item (1) above. 


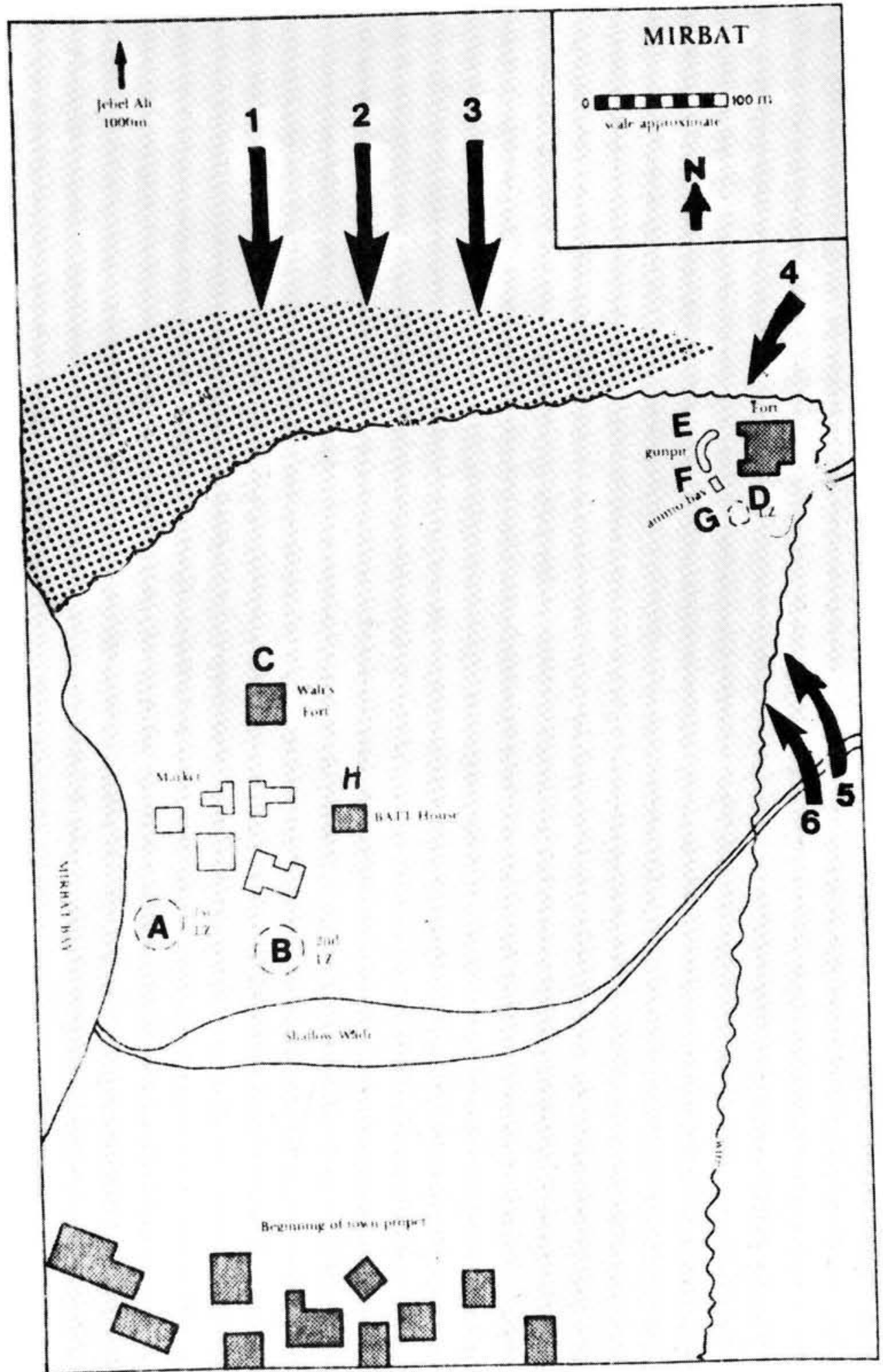

Fig (i)

\section{1-6 Attacking adoo waves}

A 1st attempted landing zone of helicopter trying to effect casualty evacuation; helicopter driven off by enemy fire.

B 2nd landing zone of helicopter, which evacuates wounded.

$\begin{array}{ll}\text { C } & \text { Wali's fort } \\ \text { D } & \text { Fort } \\ \text { E } & \text { Gun pit (25 pr) } \\ \text { F } & \text { Ammunition bay } \\ \text { G } & \text { Landing strip (not used) } \\ \text { H } & \text { HQ of SAS BATT team. }\end{array}$




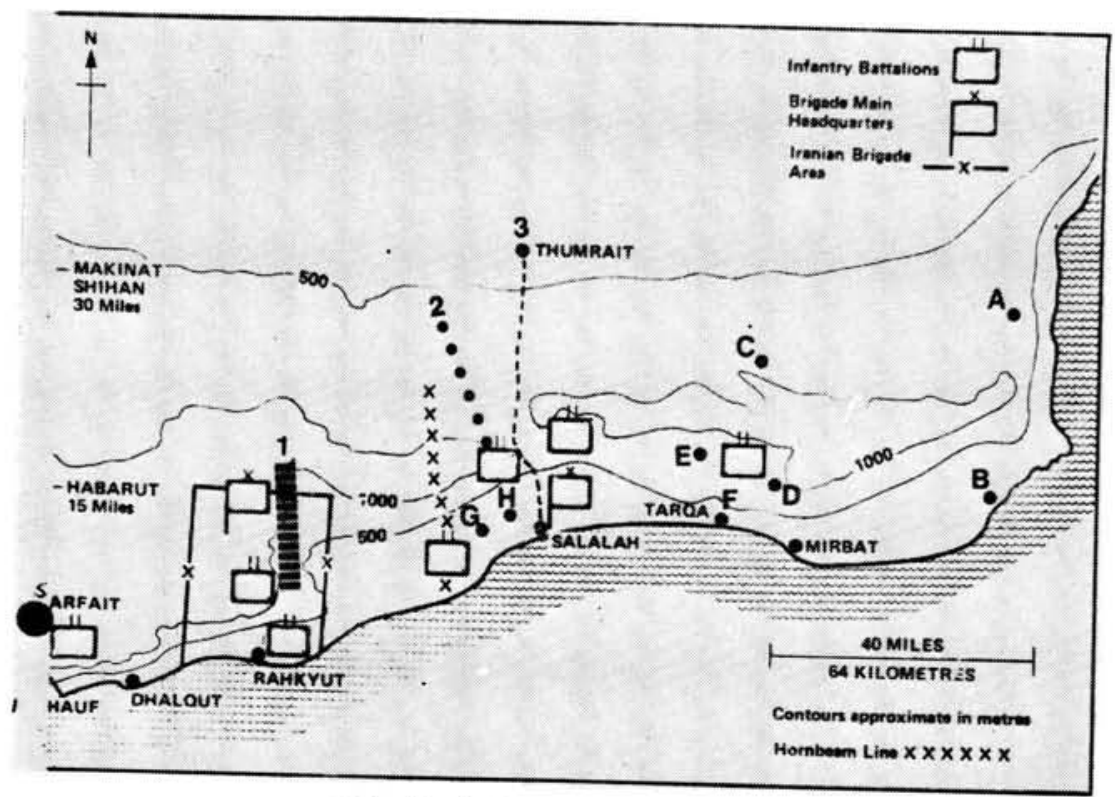

Situation in Dhofar, January 1975

Flg (ii)

$\begin{array}{llll}\text { A } & \text { Jibjat } & \text { G } & \text { Mugsayl } \\ \text { B } & \text { Sudh } & \text { H } & \text { Rayzut } \\ \text { C } & \text { Medinat Al Haq } & 1 & \text { Damavand Line } \\ \text { D } & \text { Eagle's Nest } & 2 & \text { Hammer Line } \\ \text { E } & \text { Tawi Atair } & 3 & \text { Midway road (to Northern Oman) } \\ \text { F } & \text { Tarqa } & & \end{array}$

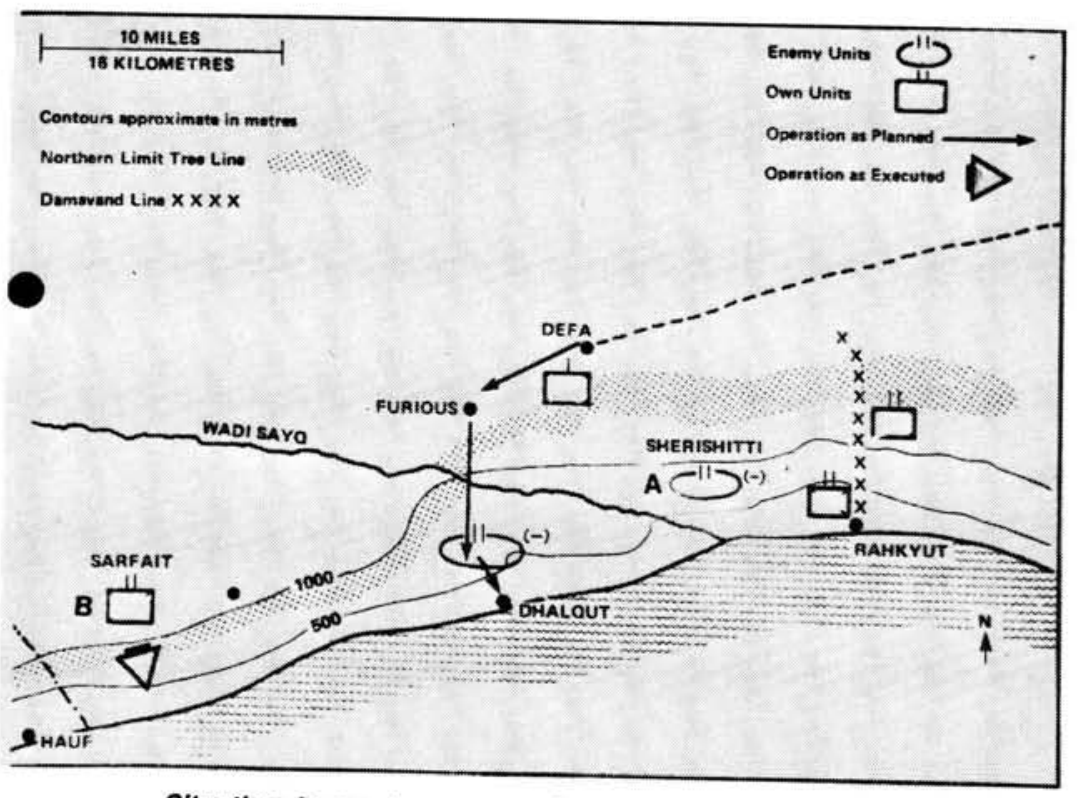

Situation in western areas, September 1975, and final operations

Flg (III)

A Main supply complex of insurgents
B $\quad$ Garrison of Muscat Regt 